\title{
Source apportionment of ambient fine particle from combined size distribution and chemical composition data during summertime in Beijing
}

\section{Z. R. Liu ${ }^{1}$, Y. S. Wang ${ }^{1}$, Q. Liu ${ }^{1,2}$, B. Hu ${ }^{1}$, and Y. Sun ${ }^{1}$}

${ }^{1}$ State Key Laboratory of Atmospheric Boundary Layer Physics and Atmospheric Chemistry (LAPC), Institute of Atmospheric Physics, Chinese Academy of Sciences, Beijing 100029, China

${ }^{2}$ Beijing Weather Modification Office, Beijing, China

Received: 4 November 2012 - Accepted: 2 January 2013 - Published: 14 January 2013

Correspondence to: Y. S. Wang (wys@dq.cern.ac.cn)

Published by Copernicus Publications on behalf of the European Geosciences Union.

\section{Source}

apportionment of ambient fine particle

Z. R. Liu et al.

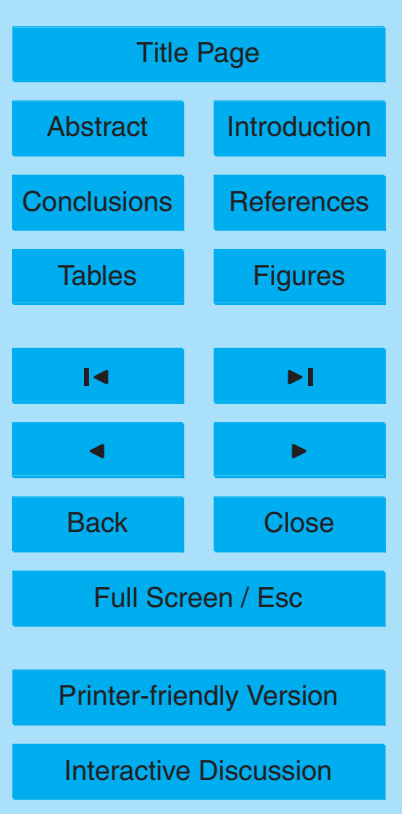




\section{Abstract}

Continuous particle number concentration and chemical composition data were collected over one month during summertime in Beijing to investigate the source apportionment of ambient fine particles. Particle size distributions from $15 \mathrm{~nm}$ to $2.5 \mu \mathrm{m}$ in di5 ameter and composition data, such as organic matter, sulfate, nitrate, ammonium, chlorine, and gaseous pollutants, were analyzed using positive matrix factorisation (PMF) which indentified eight factors: cooking, solid mode exhaust, nucleation mode exhaust, accumulation mode, secondary nitrate, secondary sulfate, coal-fired power plant and road dust. Nearly two-thirds of particle number concentrations were attributed to cook. $8 \%$ ) and motor vehicle (37.5\%), whereas road dust, coal-fired power plant and regional sources contributed $69.0 \%$ to particle volume concentrations. Local and remote sources were distinguished using size distributions associated with each factor. Local sources were generally characterised by unimodal or bimodal number distributions, consisting mostly of particles less $0.1 \mu \mathrm{m}$ in diameter, and regional sources were defined by mostly accumulation mode particles. Nearly one third of secondary nitrate and secondary sulfate was transported from the surrounding areas of Beijing during study period. Overall the introduction of combination of particle number concentration and chemical composition in PMF model is successful at separating the components and quantifying relative contributions to the particle number and volume population in a complex urban atmosphere.

\section{Introduction}

Numerous epidemiological studies have shown a consistent association of cardiovascular hospital admissions with particulate mass concentrations (Peters et al., 2000; Dominici et al., 2005; Brook et al., 2010). In addition to mass, evidence from many studies has indicated that the particle number concentration (mainly ultrafine particles, UFP, diameter $<100 \mathrm{~nm}$ ) may be a cause of adverse health effects, especially cardiovascular
ACPD

$13,1367-1397,2013$

\section{Source \\ apportionment of \\ ambient fine particle}

Z. R. Liu et al.

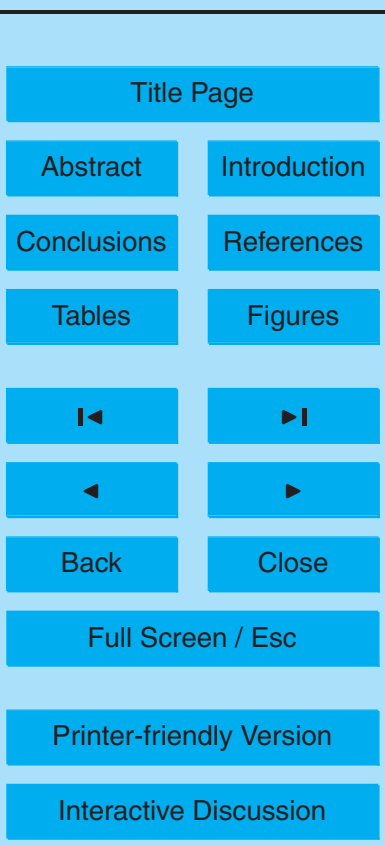


diseases (Wichmann et al., 2000; Delfino et al., 2005). Moreover, particles in ambient air are generally mixtures of materials directly released from different sources or formed as a product of gas to particle conversion. Therefore, a better understanding of the source attribution of particles in the urban atmosphere is important for investigating 5 the associations between specific particle sources and health and for policy makers to introduce suitable legislation for air quality control.

As the capital of China and a major megacity, Beijing has been experiencing great changes in the last few years. The rapid increase of the economy, population and motor vehicles makes Beijing one of the most polluted megacities in the world. A total of 15 10 stages of control measures for air pollution have been implemented since 1998 and were enhanced strongly for the 2008 Olympic Games. Primary pollutants such as $\mathrm{SO}_{2}$ and $\mathrm{PM}_{10}$ have decreased steadily in the last $10 \mathrm{yr}$ (Chan and Yao, 2008); however, fine particles remain at high levels, suggesting that past control measures have not been effective in reducing emission sources of fine particles. A clear understanding of the sources of fine particles in Beijing will effectively promote the implementation of follow-up abatement policies.

For the past decade, Beijing's atmospheric particulate pollution problem has seen a growing volume of scientific publications on source apportionment attempts. Receptor modelling methods such as positive matrix factorisation (PMF) and chemical mass balance $(\mathrm{CMB})$ are mostly used. These conventional source apportionment studies typically use chemical composition data from filter sampling to provide information on particle matter sources (Polissar et al., 2001; Song et al., 2006, 2007; Xie et al., 2008). Once particles are emitted from a given source, their size, number, and chemical composition change by several mechanisms until they are ultimately removed by natural 25 processes (Seinfeld and Pandis, 2006). Particle size distributions would be expected to remain approximately stationary at some appropriate distance from the emission source. Thus, measured spectra can help characterise source contributions and even estimate emission factors (Charron and Harrison, 2003; Janhäll et al., 2004; Costabile et al., 2009). However, conventional source apportionment studies cannot provide

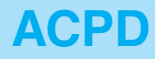

$13,1367-1397,2013$

\section{Source \\ apportionment of \\ ambient fine particle}

Z. R. Liu et al.

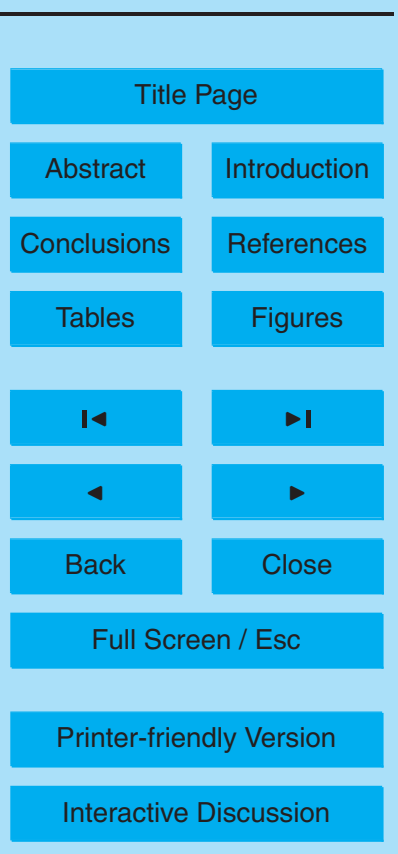


such information, as only particulate chemical composition is considered in these receptor modelling methods. Furthermore, the filter-sampling period usually lasts $24 \mathrm{~h}$ or even longer, obscuring the dynamic changes of particle size, number, and chemical composition. The result is a lack of ready source emission information. More recently, 5 several efforts have been made to use size distribution data to elicit source information (Zhou et al., 2004; Gu et al., 2011). Some of these efforts have involved the simultaneous multivariate analysis of size distribution and chemical composition data (Zhou et al., 2005; Oguleia et al., 2006). Still, high-temporal-resolution of chemical composition data is limited in these studies and obscuring a deeper understanding of the source 10 apportionment.

The objectives of this study are to identify possible sources of $\mathrm{PM}_{2.5}$ in Beijing, China. The data set is obtained from an intensive summer observation and consists of onemonth samples averaged to a $1 \mathrm{~h}$ resolution. A particle number data set (diameter 15-2500 nm) combined with measured chemical and gaseous composition data was analysed using positive matrix factorisation (PMF). This is the first instance of using source apportionment based on high-resolution particle size distribution and particle chemical composition data in the Beijing megacity.

\section{Experimental methods}

\subsection{Sampling site}

20 The sampling site was on the rooftop of a two-story building in the courtyard of the Institute of Atmospheric Physics (IAP, $39^{\circ} 58^{\prime} \mathrm{N}, 116^{\circ} 22^{\prime} \mathrm{E}$ ), which is located $10 \mathrm{~km}$ northwest of the centre of Beijing (Tiananmen Square). The site is approximately $1 \mathrm{~km}$ from the 3rd Ring Road, 250 m from the Jingzang Expressway G6, running north-south to its east, and $125 \mathrm{~m}$ from the Beitucheng West Road running east-west to its north. The site

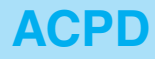

$13,1367-1397,2013$

\section{Source \\ apportionment of \\ ambient fine particle}

Z. R. Liu et al.

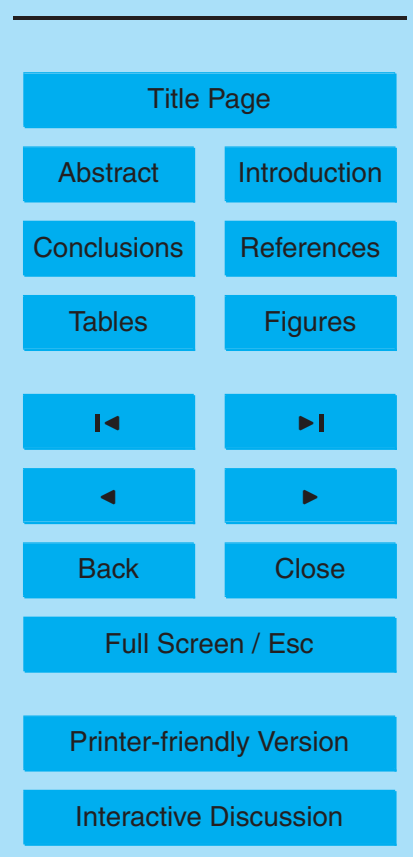


Sampling instruments were installed in an air-conditioned room with an inlet system approximately $10 \mathrm{~m}$ above ground level.

\subsection{Data description}

An intensive observation period ran from 30 July to 30 August 2011. Particle counts 5 and size distributions $(14.5-710.5 \mathrm{~nm})$ were determined using a scanning mobility particle sizer (SMPS), comprising a model TSI 3080 electrostatic classifier and a model TSI 3775 condensation particle counter (CPC), complemented by a TSI aerosol particle sizer (APS) 3321, which measures particle diameters within a range of $0.542-19.81 \mu \mathrm{m}$. A low flow $\mathrm{PM}_{10}$ inlet was used for both systems. The relative humidity within the systems was kept below $30 \%$ by adding a silica-gel dryer in the inlet line and also in the sheath air cycle to avoid condensation of water in the inlet systems during summertime. Size distributions were scanned every $10 \mathrm{~min}$. Size-dependent diffusional and gravitational losses for the inlet line have been corrected by using the empirical functions given by Willeke and Baron (1993). The data collected from these two instruments were averaged into hourly spectra and merged into one particle size spectrum matrix (diameter 14.5-2514 nm) according to the method of Beddows et al. (2010).

Hourly means of particle chemical composition and size distribution (organic matter, sulfate, nitrate, ammonium and chlorine) during the study period were measured using an Aerodyne HR-ToF-AMS. A detailed description of this instrument is given 20 in DeCarlo et al. (2006). Ambient air was sampled isokinetically into the HR-ToF-AMS from a 1.0 inch (outer diameter) stainless steel tube with an inline $\mathrm{PM}_{2.5}$ cyclone (URG2000-30EH). The total flow through the stainless steel tube was $10 \mathrm{~L} \mathrm{~min}^{-1}$, out of which about $0.1 \mathrm{~L} \mathrm{~min}^{-1}$ was sampled by the HR-ToF-AMS. The residence time of air between the inlet and the HR-ToF-AMS was estimated at $6 \mathrm{~s}$. The HR-ToF-AMS was operated under the "V" ion optical modes. Under V-mode operation, the AMS cycled through the mass spectrum (MS) mode and the particle time-of-flight (PToF) mode every $30 \mathrm{~s}$, spending $10 \mathrm{~s}$ and $20 \mathrm{~s}$, respectively, in each mode. Size distribution data are reported in units of mass-weighted aerodynamic diameter. The HR-ToF-AMS was calibrated for

\section{Source apportionment of ambient fine particle}

Z. R. Liu et al.

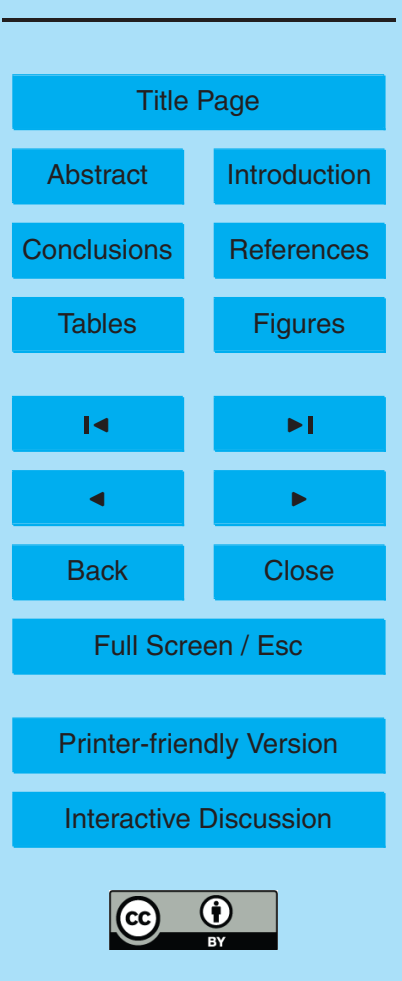


ionization efficiency (IE) and particle sizing at the beginning and in the middle of this study following the standard protocols (Jimenez et al., 2003; Drewnick et al., 2005; Liu

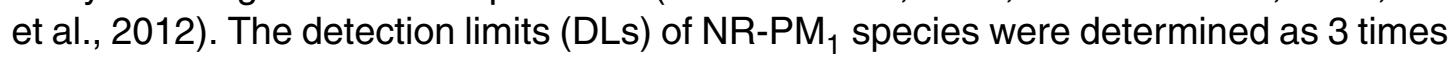
the standard deviations $(3 \sigma)$ of the corresponding signals in particle-free ambient air 5 through a HEPA filter (Zhang et al., 2005). The 5 min DLs of organics, sulfate, nitrate, ammonium, and chloride are $35,6,5,11$ and $4 \mathrm{ng} \mathrm{m}^{-3}$ respectively, which are close to the values reported in previous HR-ToF-AMS studies (Sun et al., 2011b).

Hourly means of gaseous pollutants ( $\mathrm{NO}, \mathrm{NO}_{2}, \mathrm{O}_{3}, \mathrm{SO}_{2}$ and $\mathrm{CO}$ ) were obtained from the IAP monitoring station. The data are quality-assured to national network stan10 dards and are reported to the Beijing Environmental Protection Bureau. A description of the hourly average concentrations of particle size channels, particle composition and gaseous pollutants during the study periods appear in the SI Table S1. At the same time, an automatic meteorological observation instrument called Milos520 (Vaisala, Finland) was located at the $8 \mathrm{~m}$ level and was used to observe the main meteorological 15 parameters, including pressure, temperature, humidity, and the speed and direction of wind in the atmosphere at the ground level. A description of the hourly meteorological data appears in the SI Table S2 and Fig. S1.

\subsection{Positive matrix factorisation}

A positive matrix factorisation method in the form of EPA PMF 3.0 was considered 20 to infer the unknown sources of fine particles (Norris et al., 2008). PMF has been comprehensively described by Paatero and Tapper (1994) and Paatero (1997). Details of this method appear in the supporting information. A total of 80 variables representing different particle sizes (the first 60 columns), particle chemical components (the middle 15 columns) and gaseous pollutants (the last 5 columns) were included in 25 the PMF analysis. In order to get a better source information, each chemical species was divided into three modes according to its particle size, which namely Aitken mode (AtM, 50-100 nm), condensation mode (CoM, 100-250 nm) and droplet mode (DrM, 300-800 nm) (Costabile et al., 2009), respectively. Missing number concentration

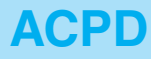

$13,1367-1397,2013$

\section{Source \\ apportionment of ambient fine particle}

Z. R. Liu et al.

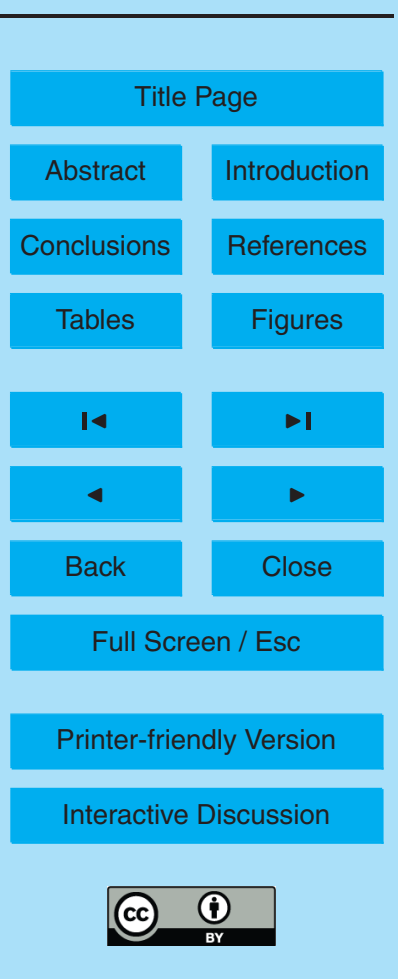


values were replaced by interpolated values of the determined values within the same size bin. For the chemical composition and gaseous pollutants data, missing concentration values in the original data set were estimated by linear interpolation of the measured concentration value. To provide the inputs needed for the analysis, the mea5 surement errors for the size distribution data and chemical composition and gaseous pollutant data were estimated from the following empirical equation:

$\sigma_{x_{i j}}=0.05\left(x_{i j}+\bar{x}\right)$

where $\sigma_{i j}$ is the calculated (estimated) measurement error, $x_{i j}$ is the observed number concentration or chemical composition and gaseous pollutants concentration, and the

$\bar{x}$ is the arithmetic mean of the reported values for $x_{i j}$.

Different numbers of factors and $F_{\text {peak }}$-values have been explored to obtain the most meaningful results. $F_{\text {peak }}$ is a parameter used in PMF2 to control rotation. In practice, one usually observes increases in the scaled residuals as well as the $Q$-value. This method of determining the "correct" number of factors has been described by Zhou et 15 al. (2004). Eight factors were selected for this study, and the $F_{\text {peak }}$-value was set to -0.4 for both the number and volume size distributions.

\subsection{Conditional probability function}

To assist in the interpretation of the source factors, the contribution values were associated with wind directions using the conditional probability function (CPF) (Kim and 20 Hopke, 2004). Hourly meteorological data were used for this analysis. Wind sectors of $20^{\circ}$ were used starting at $0^{\circ}$. Because the direction of a source is not well determined at low wind speeds, wind speeds $<1 \mathrm{~m} \mathrm{~s}^{-1}$ were excluded from this analysis. A description of CPF can be found in Ogulei et al. (2006) and Yue et al. (2008). The threshold criterion was set at the 75th percentile for defining the directionality of the sources.

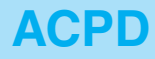

13, 1367-1397, 2013

\section{Source \\ apportionment of ambient fine particle}

Z. R. Liu et al.

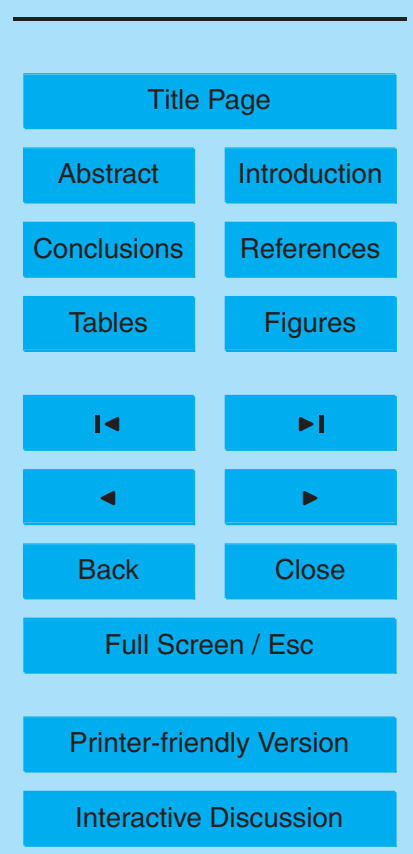




\section{Results}

The results of the PMF analysis appear in Figs. 1 and 2, which show the number and volume spectra associated with each factor, together with chemical and gaseous species, and the association with the distribution of average $241 \mathrm{~h}$ factor contributions

5 to show the diurnal pattern of each factor. The CPF values for each factor are shown in Fig. 3 to indicate the possible directions of the sources. Table 1 shows the contribution of each factor to the total number or volume of particles measured and the suggested source. Table 2 shows the percent of each chemical and gaseous species attributed to each factor.

Factor 1 shows a mode in the number distribution at $40 \mathrm{~nm}$ and a volume distribution of approximately $400 \mathrm{~nm}$ (Fig. 1). The same mode was found to be present in Taiwan by Li et al. (1993), who measured particle size distributions of sub-micrometer aerosols generated from three types of domestic cooking processes. They found the mode diameters to be between $30 \mathrm{~nm}$ and $50 \mathrm{~nm}$. More recent research confirmed this mode to 15 be associated with cooking activity (Buonanno et al., 2009). Furthermore, Factor 1 contains substantial amounts of condensation mode (34.7\%) and droplet mode $(11.9 \%)$ organic matter, but it has little correlation with secondary inorganic ions $\left(R^{2}<0.10\right)$, consistent with previous measurements that aerosols emitted from Chinese cooking are almost organic compounds (He et al., 2004). A clear and unique diurnal pattern of this factor provides another piece of strong evidence for it being cooking related: it presented high values at noon (11:00-13:00) and in the evening (18:00-20:00), which, in accordance with dining hours of the local residents (Huang et al., 2012). Two main Chinese restaurants are located less than $100 \mathrm{~m}$ northwest and southeast of the sampling site, and the directionality of this source, as determined by CPF analysis (Fig. 3), clearly corresponds to these directions. Due to the unique Chinese cooking habits and culture, cooking emissions have been regarded as one of the major organic aerosol sources in Chinese unban environments (He et al., 2004; Zhao et al., 2007). Therefore, it was a consequential result to identify a notable cooking-related aerosol component in this

\section{Source apportionment of ambient fine particle}

Z. R. Liu et al.

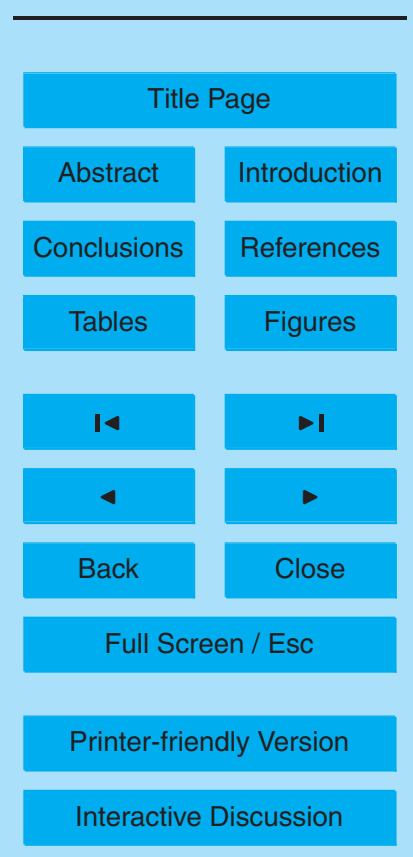


study. Factor 1 is the largest contributor to the particle number $(22.8 \%)$ but only makes a small contribution to particle volume (3.8\%).

Factor 2 shows a major mode at approximately $70 \mathrm{~nm}$ in the number distribution and $200 \mathrm{~nm}$ in the volume distribution, which is indicative of locally generated material 5 (Ondov and Wexler, 1998). This size distribution is similar to that obtained from measurements made near major Los Angeles freeways (Zhu and Hinds, 2002). Factor 2 has a high positive correlation with $\mathrm{NO}_{\mathrm{x}}$, which suggests a relationship with on-road traffic emissions. Considering that this factor contains a high amount of condensation mode $(21.7 \%)$ and droplet mode $(17.8 \%)$ organic matter and a considerable amount 10 of condensation mode sulphate $(15.3 \%)$, Factor 2 is chemically consistent with diesel particle (Kittelson, 1998) and likely corresponds to solid carbonaceous particles from diesel exhaust, as characterised by Zhu et al. (2010) in a highway tunnel. The diurnal variation of this factor suggests a night-time emission source, consistent with the number of heavy diesel trucks on the nearby road, which are only allowed to travel along or within Beijing's Fifth Ring Road during the night (00:00-06:00) while during the daytime the vehicles are dominated by gasoline-powered passenger cars, which contribute $91 \%$ of the total number of vehicles in urban area of Beijing (source: Beijing Transportation Research Centre), further supporting that this factor originates from diesel vehicles. The result of the CPF analysis suggests this source appear to be located in the north-eastern, eastern and south-western directions of the site. The first two directions correspond to the locations of Jingzang Expressway G6 and the Beitucheng West Road, which are $250 \mathrm{~m}$ and $125 \mathrm{~m}$ from the observation site, respectively. The direction from south-western maybe suggests a diesel exhaust source transported from the 3rd Ring Road about $1 \mathrm{~km}$ away from the observation site. Factor 2 makes the secondary largest contribution to particle number (18.8\%) and a modest contribution to particle volume (8.7\%).

Factor 3 shows a main particle number nucleation mode at $20 \mathrm{~nm}$ and a minor accumulation mode at $100 \mathrm{~nm}$, making it the smallest aerosol size mode factor obtained by the PMF analysis. The strong associations with both northerly and northeasterly

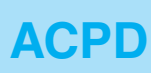

$13,1367-1397,2013$

\section{Source \\ apportionment of ambient fine particle}

Z. R. Liu et al.

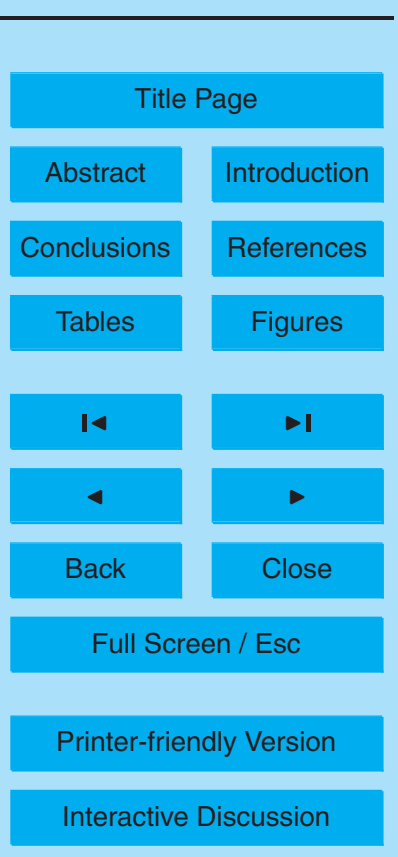

Interactive Discussion 
wind directions and with traffic-generated primary pollutants $\left(\mathrm{NO}_{\mathrm{x}}\right)$ suggest this factor is also likely to be traffic-associated. A higher ratio of $\mathrm{NO}$ to $\mathrm{NO}_{2}$ indicates Factor 3 is originated from fresh vehicle exhaust compared with Factor 2 (Table 2). Similar particle size distribution was present in Dall'Osto et al. (2012) which attributed it with nucle5 ation mode particles generated during the dilution of vehicle exhaust emission. Casati et al. (2007) reported this mode as occurring within the range of $10-30 \mathrm{~nm}$ in diameter. Charron and Harrison (2003) and Janhall et al. (2004) also found this mode to be strongest in the morning, probably due to the low temperatures at this time of day. A unique diurnal profile shows, between the morning and evening traffic rush hour spikes, 10 a major third spike peaking during noontime. Whilst we attribute the two morning and evening spikes to the nucleation mode particles generated during the dilution of vehicle exhaust emission, it should be borne in mind that condensation process but not nucleation process should be prevalent during the dilution of vehicle exhaust in the highly polluted atmosphere of Beijing. We attribute the midday peak to photochemistry nucle15 ation events. New particle formation events were observed on around $40 \%$ during one year study in Beijing urban atmosphere (Wu et al., 2007). Figure 4 shows the presence of a nucleation event on 31 July that could have contributed to the observed levels of nucleation mode particles. The right-hand tail of the size distribution possibly indicates growth of the particles by coagulation or condensation on pre-existing particles. This 20 factor contributed $18.7 \%$ to the number concentration but only $2.4 \%$ to the volume contribution, as these particles carry very little mass per particle.

Factor 4 makes the largest contribution (32.2\%) to the particle volume and a considerable contribution (13.8\%) to the particle number. This factor is closely associated with secondary inorganic and organic matter and explains most of the droplet mode 25 sulfate $(37.3 \%)$, droplet mode nitrate $(42.1 \%)$ and a large amount of the droplet mode organic matter $(21.2 \%)$. Factor 4 has classic accumulation mode peaks at approximately $150 \mathrm{~nm}$ in the number distribution and $300 \mathrm{~nm}$ in the volume distribution, and it appears to be an accumulation mode component regionally transported from hundreds or thousands of kilometres away and mixed down to the ground level. Factor 4's

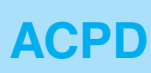

13, 1367-1397, 2013

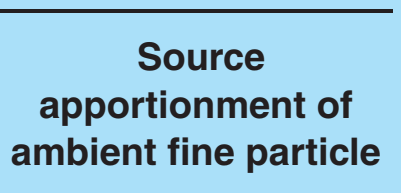

Z. R. Liu et al.

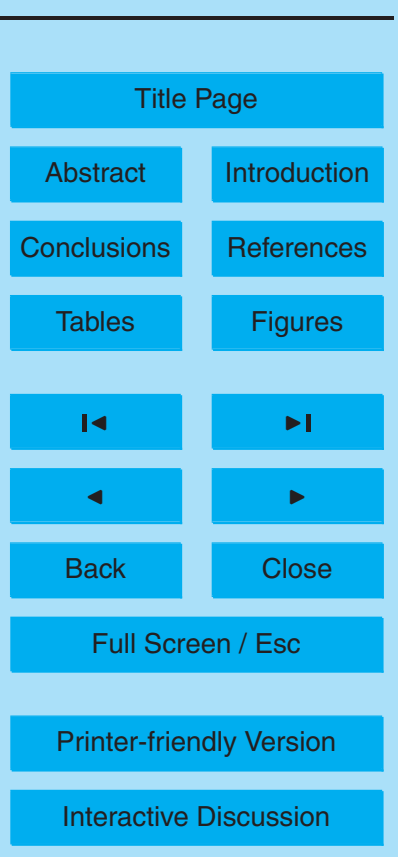

Interactive Discussion 
wind direction is predominantly associated with the southeast, southwest and northeast sectors, the first two regions that, including the Hebei and Shandong provinces, have been proved to be major contributors to particle pollution in Beijing by the way of the regional air mass transport of anthropogenic emissions (Zhu et al., 2011). The 5 directional association with northeast region, which with less emission pointed out by emission inventory and satellite studies (Guo et al., 2009; Zhang et al., 2009), suggests this is a component of background air regionally transported.

Factor 5 contains high amounts of nitrate, organic matter and sulfate and has significant correlations with $\mathrm{NO}_{\mathrm{x}}$ and $\mathrm{SO}_{2}$. Most of the particles in Factor 5 are less than $10100 \mathrm{~nm}$ with a mode at approximately $50 \mathrm{~nm}$, suggests a relationship with locally generated materials. This factor explains the largest amount of Aitken mode (47.8\%) and condensation mode (39.7\%) of the apportioned nitrate (Table 2) and is assigned as a secondary nitrate source. The diurnal variation of this factor suggests a source predominantly in the evening, and the highest concentration appeared in the early morning when a combination of low ambient temperatures and high relative humidity favors the formation of particulate nitrate (SI Fig. S4). Low concentrations are observed in the afternoons, when high temperatures and low relative humidity lead to the dissociation of particulate nitrate back to ammonia and nitric acid (Park et al., 2005). CPF results suggest that this source may be association with emissions coming from the direction of the Jingzang Expressway G6 and the Beitucheng West Road. This factor, therefore, can be recognized as secondary nitrate that has been formed from atmospheric processing of local $\mathrm{NO}_{\mathrm{x}}$ emissions. This factor does not make a large contribution to particle number $(8.9 \%)$ or to particle volume $(5.6 \%)$, though it is equal.

Factor 6 showed a bimodal particle size distribution with a major peak at 20-30 nm and a second one at 100-200nm. This factor's diurnal pattern suggests a source predominantly in the afternoon with little contribution at night, which is a completely different diurnal pattern from that of Factor 5 . This factor contains a large amount of droplet mode $(28.2 \%)$ and condensation mode $(25.4 \%)$ of appointment sulphate combined with particles mainly smaller than $200 \mathrm{~nm}$, suggesting that this factor is associated with

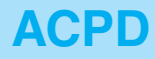

13, 1367-1397, 2013

\section{Source \\ apportionment of \\ ambient fine particle}

Z. R. Liu et al.

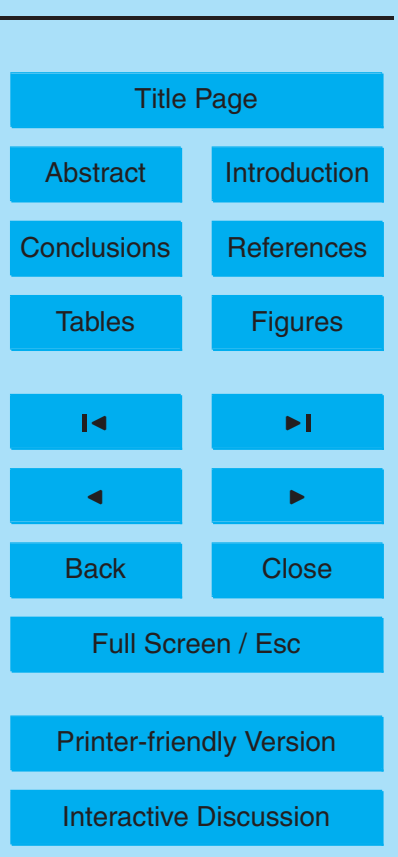


secondary sulfate formed mainly through in-cloud or aerosol droplet process and gas condensation process, consistent with the formation processes of secondary sulfate in previous study (Guo et al., 2010). Furthermore, Factor 6 contains the vast majority of $\mathrm{O}_{3}(77.6 \%)$ and substantial amount of $\mathrm{SO}_{2}(31.9 \%)$, and its diurnal pattern is consis5 tent with that of $\mathrm{O}_{3}$ (SI Fig. S3), indicating a strong photochemical reaction ability that drives oxidation from $\mathrm{SO}_{2}$ to sulfate. According to the values of previous studies, local $\mathrm{SO}_{2}$ emission sources are known to contribute to aerosol sulfate loading (Zhang et al., 2007). The CPF plot points in the south-easterly and south-westerly directions from the site as the probable dominant directions, corresponding to the directions of the 10 known coal-fired power plants, namely, the Beijing Thermal power station $\left(39^{\circ} 53^{\prime} \mathrm{N}\right.$, $\left.116^{\circ} 31^{\prime} \mathrm{E}\right)$ and the Beijing 3rd Thermal power station $\left(39^{\circ} 48^{\prime} \mathrm{N}, 116^{\circ} 08^{\prime} \mathrm{E}\right)$. This directionality suggests that components such as $\mathrm{SO}_{2}$ may have been transported from these distant power plants, causing local photochemical reactions to occur. Factor 6 does not make a large contribution to particle number $(7.9 \%)$ but makes a considerable contribution to particle volume (10.5\%).

Factor 7 shows a similar mode with that of Factor 2 at approximately $70 \mathrm{~nm}$ in the number distribution; its volume distribution, however, shows a mode approximately $500 \mathrm{~nm}$ larger than that of Factor 2, suggesting that the particles in Factor 7 were also locally generated but more aged than Factor 2 . These particles should be transported longer distances than the particles in Factor 2 and should not be generated by traffic on the nearby Jingzang Expressway G6 or the Beitucheng West Road. This factor shows a strong association with sulfate and a modest association with combustion gases $\left(\mathrm{NO}_{\mathrm{x}}\right.$ and $\mathrm{SO}_{2}$ ), and it explains a large amount of droplet mode sulfate $(10.5 \%)$. The potential sources of this factor are located in the south-easterly and south-westerly directions, which, as suggested by the CPF analysis (Fig. 3), correspond to the directions of the known coal-fired power plants, namely, the Beijing Thermal power station $\left(39^{\circ} 53^{\prime} \mathrm{N}\right.$, $\left.116^{\circ} 31^{\prime} \mathrm{E}\right)$ and Beijing 3rd Thermal power station $\left(39^{\circ} 48^{\prime} \mathrm{N}, 116^{\circ} 08^{\prime} \mathrm{E}\right)$, both of which are in a straight-line distance of approximately $25 \mathrm{~km}$. Local sulfate emissions result when $\mathrm{SO}_{2}$ adsorbs to newly formed combustion particles and undergoes oxidation into

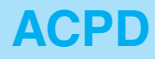

$13,1367-1397,2013$

\section{Source \\ apportionment of \\ ambient fine particle}

Z. R. Liu et al.

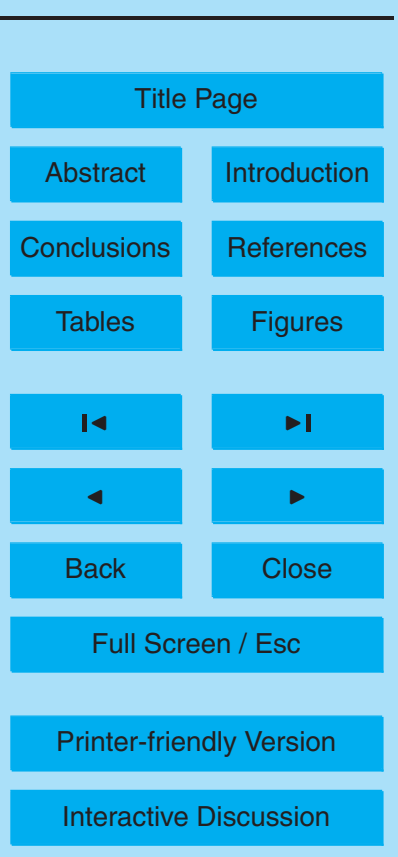


sulfate (Kerminen et al., 2000). These newly formed sulfates, combined with other air pollutants emitted by coal-fired power plants, may be transported to the receptor site. Factor 7 makes a large contribution to the volume concentration $(21.3 \%)$, but a small contribution $(6.8 \%)$ to number concentration.

5 Factor 8 makes a large contribution to the particle volume concentration $(15.5 \%)$, but it contributes least to the particle number concentration (2.3\%). This factor shows a mode at approximately $150 \mathrm{~nm}$ in the number distribution and a peak in the volume distribution, whose maximum lies somewhere above $2.5 \mu \mathrm{m}$ diameter. This source shows a modest association with organic matters, nitrate, ammonium and chlorine, suggesting 10 this component may be associated with a local source from background urban fugitive dust or roadway dust (Han et al., 2007); considering that this factor correlates positively with the traffic-generated primary pollutants $\left(\mathrm{NO}_{\mathrm{x}}\right)$, the latter appears more probable. Factor 8's wind direction is predominantly associated with the southeast sector, corresponding to the locations of Jingzang Expressway G6. As Jingzang Expressway G6 15 locates above ground, its road dust is easier to spread with wind to receptor site than the Beitucheng West Road, though the latter is closer to receptor site. The diurnal pattern of this factor suggests a source predominantly in the evening, when the mixed layer height reached its lowest value, and a weak atmospheric convection capability favours the road dust reaching the ground by dry deposition.

\section{Discussion}

\subsection{Comparison with other studies}

The source contributions to fine particles obtained from this study are compared with previous studies conducted in Beijing and other megacities (Table 3). Most previous studies have estimated source contributions based on mass concentrations; the source contributions calculated in the present study were based on volume and number concentration. The particle density from different sources is usually different, so the volume

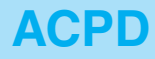

$13,1367-1397,2013$

\section{Source \\ apportionment of \\ ambient fine particle}

Z. R. Liu et al.

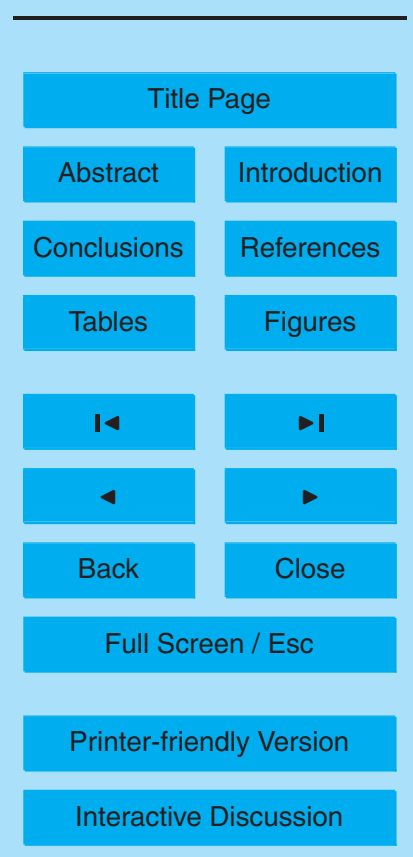


concentration should not equal the mass concentration. However, because it is difficult to obtain the particle density from different sources, we assume the volume concentration is equivalent to the mass concentration in the present study, making the comparison possible.

5 The quantified contribution of motor vehicle emissions to ambient $\mathrm{PM}_{2.5}$ in Beijing increased from $5.9 \%$ in 2000 to $14.9 \%$ in 2004 , comparable with that of this study $(11.1 \%)$. The contribution from secondary sulfate is $10.5 \%$ in the present study, much lower than that of previous studies in Beijing or megacities in the USA (Table 3). It should be noted that the secondary sulfate in this study is only that of local origin; 10 the secondary sulfate in previous studies, however, contains both local and regionally transported particles, as will be discussed in the follow section. The contribution from secondary nitrate is more or less the same with that of previous studies. The contribution from coal consumption is much higher than previous studies conducted in Beijing, possibly because other emission sources, such as biomass burning, may be included in 15 coal consumption, making the contribution of this source greater than in previous studies. The contribution from road dust is much higher than previous studies conducted in Beijing, but comparable with that of London, the increasing of motor vehicles travel on road should responsible for the growth of this source. Few studies have examined the impact of cooking on ambient air quality; the quantified contributions of cooking emissions estimated in the present study are roughly the same as those of Chen et al. (2012).

The source contribution to fine particle number concentrations for the indentified sources in the present study is nearly the same as that of Harrison et al. (2011) and Pey et al. (2009), except for the motor vehicle source and cooking source. Vehicles exhaust is the dominant source to the total particle number concentration in the Europe cities (>60\%), whereas, its contribution to the total particle number concentration is much lower in Beijing (37.5\%), the diversification of the particle sources in Beijing should response for this kind of contribution divergence. The volume concentration contribution of cooking in this study is lower, but with a much higher number concentration

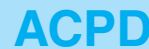

13, 1367-1397, 2013

\section{Source \\ apportionment of \\ ambient fine particle}

Z. R. Liu et al.

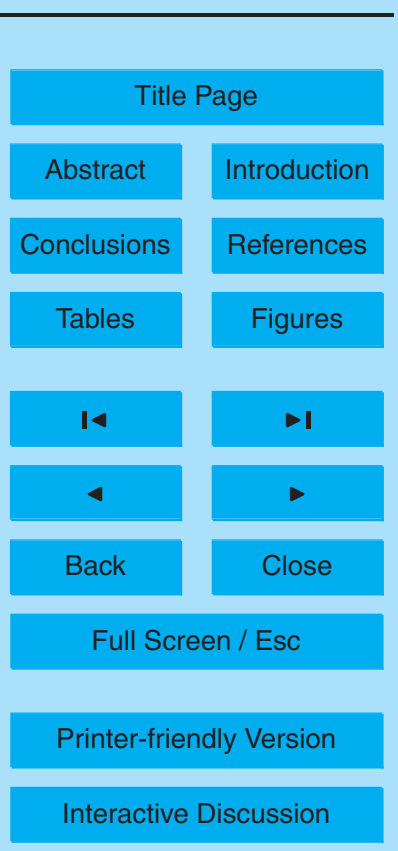


contribution than that of Harrison et al. (2011). Under the same cooking conditions, the Chinese cooking style usually produces more UFP concentrations than the western cooking style, as there is more frying activity in the former (Zhang et al., 2010). Consequently, a larger percentage of the cooking contribution to the particle number 5 concentration in this study could be reasonable.

\subsection{Local and remote secondary aerosol}

In previous source apportionment studies, it has been difficult to distinguish between local origin and regional transport for secondary aerosols, such as secondary sulfate and secondary nitrate, because of the lack of high-temporal-resolution physical and chemical information on the particles. In the present study, local and remote sources were successfully distinguished based on the particle size characteristics of each source, where local sources were generally characterised by unimodal or bimodal number distributions consisting mostly of particles less $0.1 \mu \mathrm{m}$ in diameter. The regional source was defined mostly by accumulation mode particles. More than one-third of the secondary nitrate and secondary sulfate in Beijing was transported from the surrounding areas of Beijing (Table 2). Locally originated nitrate was mostly from atmospheric processing of local $\mathrm{NO}_{x}$ emissions during night-time, and locally originated sulfate was mostly formed through in-cloud or aerosol droplet process and gas condensation process.

\subsection{Primary and secondary organic aerosol}

Current knowledge regarding organic aerosols, including POAs emitted directly from primary sources and SOAs from the oxidation of VOCs, is still very limited. Most particle source apportion articles have been unable to distinguish primary and secondary organic aerosols because these studies have used $24 \mathrm{~h}$ or $12 \mathrm{~h}$ particle filter samples, thus lacking high-temporal-resolution physical and chemical information. However, such information is sufficient in this study and provides an opportunity to explore

\section{Source apportionment of ambient fine particle}

Z. R. Liu et al.

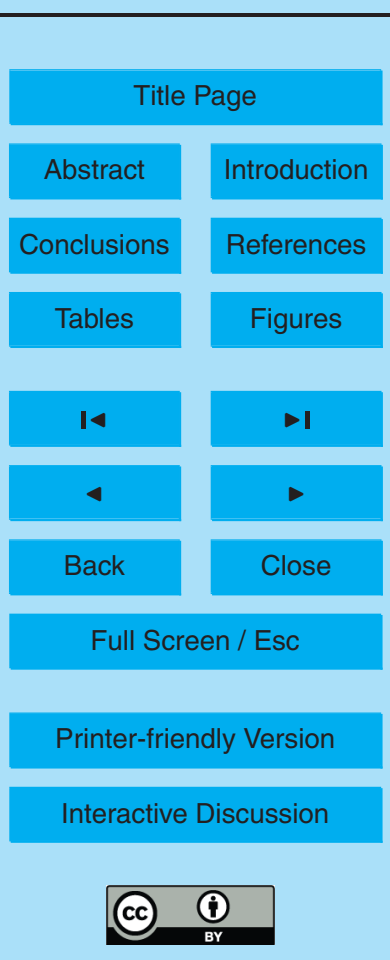


the probably formation mechanisms of SOAs. According to the previous analysis, organic aerosols are mainly included in six types of sources (Table 2). Four of these types can be regarded as directly emitted from primary sources or aged regional transported organic aerosols: cooking, solid carbon from exhaust, accumulation mode and 5 road dust. The organic aerosols from the other two sources are probably from secondary formation (secondary sulfate and secondary nitrate). SOA is formed through the gas-phase oxidation of VOCs by reactions with the hydroxyl radical $(\mathrm{OH}), \mathrm{O}_{3}$ and $\mathrm{NO}_{3}$ (Hallquist et al., 2009). Organic matter contained in the secondary sulfate source ( $24.2 \%$ in Aitken mode and $15.6 \%$ in droplet mode) is most likely due to the oxida10 tion of $\mathrm{VOCs}$ via $\mathrm{O}_{3}$ and $\mathrm{OH}$, as the photochemical production of sulfate is generated at the same time (Sun et al., 2011a). It is interesting to note that a larger amount of organic matter $(30.6 \%$ in Aitken mode and $22.0 \%$ in droplet mode) appears in the secondary nitrate source. Because the primary source of organic matter at night can be attributed to Factor 2, this portion of organic matter at night could be secondarily generated. Most laboratory (Hallquist et al., 2009; Kroll and Seinfeld, 2008) and field (Jimenez et al.,2009; Hildebrandt et al., 2010) SOA studies have focused on the role of oxidation via $\mathrm{O}_{3}$ and $\mathrm{OH}$ as SOA sources, but few have focused on the oxidation pathway of $\mathrm{NO}_{3}$. A recently study conducted in Bakersfield, California, indicates that most night-time secondary $\mathrm{OA}$ is due to the $\mathrm{NO}_{3}$ product of anthropogenic $\mathrm{NO}_{\mathrm{x}}$ emissions (Rollins et al., 2012), suggesting the importance of $\mathrm{NO}_{3}$ in the formation of SOA. That study supports the presence of organic aerosol in the secondary nitrate source, though a more detail analysis should be performed in the future. From the above analysis, we can conclude that the secondary sources are responsible for $36.7 \%$ of the OC, broadly consistent with estimates of $38.4 \%$ by Guo et al. (2012) conducted during summertime

\subsection{Implications for future abatement policy}

In this study, the most important sources for particle volume concentration were road dust, coal-fired power plant and regional sources, these three sources contributed more
13, 1367-1397, 2013

\section{Source \\ apportionment of \\ ambient fine particle}

Z. R. Liu et al.

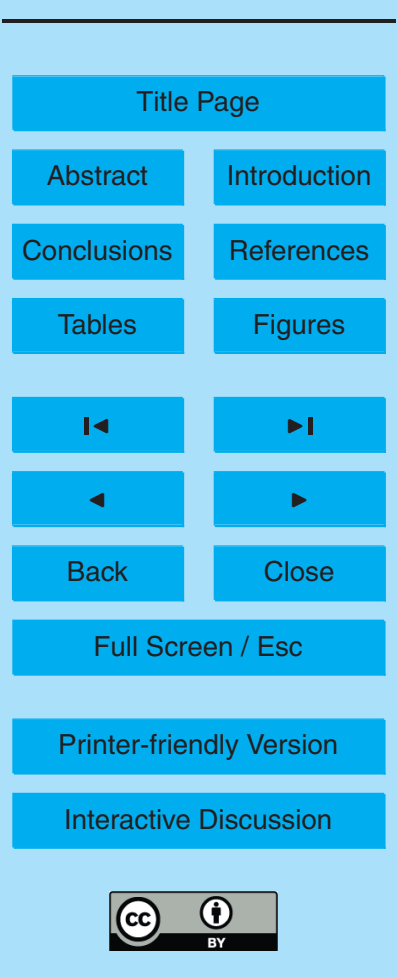


than two thirds of fine particle volume concentration in summertime of Beijing. This result suggests that cutting down emissions from road dust and power plant will effectively decrease the concentration of fine particle and improve the air quality in Beijing. At the same time, it should be aware that the highly polluted atmosphere of Beijing 5 is also attributed to the regional air pollution, as the contribution of regional sources to the volume concentration was estimate to $32.2 \%$ in this study. Improving Beijing's air quality can not only be achieved by Beijing's own effort, but also need collaborative governance of emission sources in the surrounding areas. When concerning the particle number concentration, nearly two-thirds of the particulate number concentra10 tion was contributed from cooking (22.8\%) and motor vehicles (37.5\%). This result suggests cooking emissions can be regarded as one of the major aerosol sources in Beijing unban environments, which is ignored or do not pay sufficient attention to current abatement policies and control measures should be implemented in future abatement policy. Furthermore, executing stricter emission standards and reducing pollution caused by vehicle exhaust is still an effective way to improve the air pollution and reduce the health risks caused by the highly particle number concentration especially for the ultrafine particles of Beijing.

\section{Conclusions}

Combining particle size distribution and chemical composition data sets resulted in a

better identification of sources contributing to fine particles in Beijing's air. Using the PMF model, eight sources were successfully identified from the size distribution, directional association, diurnal variation and their relationship to chemical composition and gaseous pollutants. The aforementioned analysis results in the obtaining of specific emission sources such as cooking, solid mode exhaust, nucleation mode exhaust,

\section{act}

road dust. Nearly two-thirds of the particulate number concentration was contributed from motor vehicles (37.5\%) and cooking (22.8\%), and more than two thirds of the fine 
particles volume concentrations was attributed to road dust (15.5\%), coal-fired power plant $(21.3 \%)$ and regional transport $(32.2 \%)$. Local and remote secondary aerosols were also successfully distinguished in the present study: local sources were generally characterised by unimodal or bimodal number distributions consisting mostly of particles less $0.1 \mu \mathrm{m}$ in diameter. The regional source was defined by mostly accumulation mode particles. Based on this size characteristic, secondary sulfate and secondary nitrate were first distinguished from locally originated and regionally transported, and primary organic aerosols and secondary organic aerosols were also successfully separated. This method of source apportionment may be particularly important for studying complex urban aerosols.

\section{Supplementary material related to this article is available online at: http://www.atmos-chem-phys-discuss.net/13/1367/2013/ acpd-13-1367-2013-supplement.pdf.}

Acknowledgements. This work is supported by the Knowledge Innovation Project of the Chi-

of Beiiing (No. D09040903670902). We thank K Schaefer for his insightful and helpful comments for this manuscript. We also sincerely thank G. R. Liu, W. K. Gao and W. Zhang for their cooperation during the intensive observation period.

\section{References}

Beddows, D. C. S., Dall'osto, M., and Harrison, R. M.: An enhanced procedure for the merging of atmospheric particle size distribution data measured using electrical mobility and time-offlight analysers, Aerosol Sci. Technol., 44, 930-938, 2010.

Brook, R. D., Rajagopalan, S., Pope, C. A., Brook, J. R., Bhatnagar, A., Diez-Roux, A. V., Holguin, F., Hong, Y. L., Luepker, R. V., Mittleman, M. A., Peters, A., Siscovick, D., Smith, S. C.,
Whitsel, L., and Kaufman, J. D.: Particulate matter air pollution and cardiovascular disease

1384
13, 1367-1397, 2013

\section{Source \\ apportionment of \\ ambient fine particle}

Z. R. Liu et al.

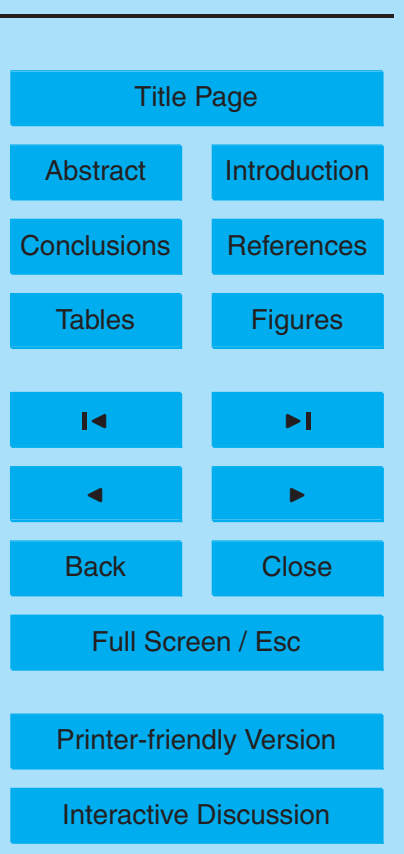

Interactive Discussion 
an update to the scientific statement from the American Heart Association, Circulation, 121, 2331-2378, 2010.

Buonanno, G., Morawska, L., and Stabile, L.: Particle emission factors during cooking activities, Atmos. Environ., 43, 3235-3242, 2009.

5 Casati, R., Scheer, V., Vogt, R., and Benter, T.: Measurement of nucleation and soot mode particle emission from a diesel passenger car in real world and laboratory in situ dilution, Atmos. Environ., 41, 2125-2135, 2007.

Chan, C. K. and Yao, X. H.: Air pollution in mega cities in China, Atmos. Environ., 42, 1-42, 2008.

10 Charron, A. and Harrison, R. M.: Primary particle formation from vehicle emissions during exhaust dilution in the roadside atmosphere, Atmos. Environ., 37, 4109-4119, 2003.

Chen, Y. J., Zheng, M., Edgerton, E. S., Ke, L., Sheng, G. Y., and Fu, J. M.: $\mathrm{PM}_{2.5}$ source apportionment in the southeastern US: Spatial and seasonal variations during 2001-2005, J. Geophys. Res., 117, D08304, doi:10.1029/2011JD016572, 2012.

Costabile, F., Birmili, W., Klose, S., Tuch, T., Wehner, B., Wiedensohler, A., Franck, U., König, K., and Sonntag, A.: Spatio-temporal variability and principal components of the particle number size distribution in an urban atmosphere, Atmos. Chem. Phys., 9, 3163-3195, doi:10.5194/acp-9-3163-2009, 2009.

Dall'Osto, M., Beddows, D. C. S., Pey, J., Rodriguez, S., Alastuey, A., Harrison, Roy M., and Querol, X.: Urban aerosol size distributions over the Mediterranean city of Barcelona, NE Spain, Atmos. Chem. Phys., 12, 10693-10707, doi:10.5194/acp-12-10693-2012, 2012.

DeCarlo, P. F., Kimmel, J. R., Trimborn, A., Northway, M. J., Jayne, J. T., Aiken, A. C., Gonin, M., Fuhrer, K., Horvath, T., Docherty, K. S., Worsnop, D. R., and Jimenez, J. L.: Field-Deployable, High-Resolution, Time-of-Flight Aerosol Mass Spectrometer, Anal. Chem., 78, 8281-8289, 2006.

Delfino, R. J., Sioutas, C., and Malik, S.: Potential role of ultrafine particles in associations between airborne particle mass and cardiovascular health, Environ. Health Perspect., 113, 934-946, 2005.

Dominici, F., McDermott, A., Daniels, M., Zeger, S. L., and Samet, J. M.: Revised analyses of the national morbidity, mortality, and air pollution study: mortality among residents of 90 cities, J. Toxicol. Environ. Health -Part A-Current Issues, 68, 1071-1092, 2005.

Drewnick, F., Hings, S. S., DeCarlo, P. F., Jayne, J. T., Gonin, M., Fuhrer, K., Weimer, S., Jimenez, J. L., Demerjian, K. L., Borrmann, S., and Worsnop, D. R.: A new Time-of-Flight

\section{Source \\ apportionment of ambient fine particle}

Z. R. Liu et al.

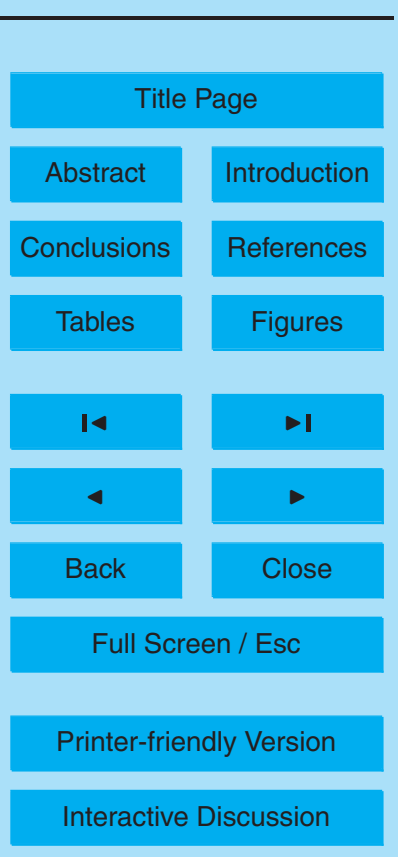


Aerosol Mass Spectrometer (ToF-AMS) - Instrument description and first field deployment, Aerosol Sci. Tech., 39, 637-658, 2005.

Gu, J. W., Pitz, M., Schnelle-Kreis, J., Diemer, J., Reller, A., Zimmermann, R., Soentgen, J., Stoelzel, M., Wichmann, H. E., Peters, A., and Cyrys, J.: Source apportionment of ambient 5 particles: Comparison of positive matrix factorization analysis applied to particle size distribution and chemical composition data, Atmos. Environ., 45, 1849-1857, 2011.

Guo, J. P., Zhang, X. Y., Che, H. Z., Gong, S. L., An, X. Q., Cao, C. X., Guang, J., Zhang, H., Wang, Y. Q., Zhang, X. C., Xue, M., Li, X. W.: Correlation between PM concentrations and aerosol optical depth in eastern China, Atmos. Environ., 43, 5876-5886, 2009.

10 Guo, S., Hu, M., Wang, Z. B., Slanina, J., and Zhao, Y. L.: Size-resolved aerosol water-soluble ionic compositions in the summer of Beijing: implication of regional secondary formation, Atmos. Chem. Phys., 10, 947-959, doi:10.5194/acp-10-947-2010, 2010.

Guo, S., Hu, M., Guo, Q. F., Zhang, X., Zheng, M., Zheng, J., Chang, C. C., Schauer, J. J., and Zhang, R. Y.: Primary Sources and Secondary Formation of Organic Aerosols in Beijing, China, Environ. Sci. Technol., doi:10.1021/es2042564, 2012.

Hallquist, M., Wenger, J. C., Baltensperger, U., Rudich, Y., Simpson, D., Claeys, M., Dommen, J., Donahue, N. M., George, C., Goldstein, A. H., Hamilton, J. F., Herrmann, H., Hoffmann, T., linuma, Y., Jang, M., Jenkin, M. E., Jimenez, J. L., Kiendler-Scharr, A., Maenhaut, W., McFiggans, G., Mentel, Th. F., Monod, A., Prévôt, A. S. H., Seinfeld, J. H., Surratt, J. D., Szmigielski, R., and Wildt, J.: The formation, properties and impact of secondary organic aerosol: current and emerging issues, Atmos. Chem. Phys., 9, 5155-5236, doi:10.5194/acp9-5155-2009, 2009.

Han, L. H., Zhuang, G. S., Cheng, S. Y., Wang, Y., and Li J.: Characteristics of re-suspended road dust and its impact on the atmospheric environment in Beijing, Atmos. Environ., 41, 7485-7499, 2007.

Harrison, R. M., Beddows, D. C. S., and Dall'Osto, M.: PMF analysis of wide-range particle size spectra collected on a major highway, Environ. Sci. Technol., 45, 5522-5528, 2011.

He, L. Y., Hu, M., Huang, X. F., Yu, B. D., Zhang, Y. H., and Liu, D. Q.: Measurement of emissions of fine particulate organic matter from Chinese cooking, Atmos. Environ., 38, 6557-6564, $30 \quad 2004$

Hildebrandt, L., Kostenidou, E., Mihalopoulos, N., Worsnop, D. R., Donahue, N. M., and Pandis, S. N.: Formation of highly oxygenated organic aerosol in the atmosphere: Insights 
from the Finokalia Aerosol Measurement Experiments, Geophys. Res. Lett., 37, L23801, doi:10.1029/2010GL045193, 2010.

Huang, X.-F., He, L.-Y., Xue, L., Sun, T.-L., Zeng, L.-W., Gong, Z.-H., Hu, M., and Zhu, T.: Highly time-resolved chemical characterization of atmospheric fine particles during 2010 Shanghai

$5 \quad$ World Expo, Atmos. Chem. Phys., 12, 4897-4907, doi:10.5194/acp-12-4897-2012, 2012.

Janhäll, S., Jonsson, Åsa. M., Molnár, P., Svensson, E. A., and Hallquist, M.: Size resolved traffic emission factors of submicrometer particles, Atmos. Environ., 38, 4331-4340, 2004.

Jimenez, J. L., Jayne, J. T., Shi, Q., Kolb, C. E., Worsnop, D. R., Yourshaw, I., Seinfeld, J. H., Flagan, R. C., Zhang, X. F., Smith, K. A., Morris, J. W., and Davidovits, P.: Ambient aerosol sampling with an Aerosol Mass Spectrometer, J. Geophys. Res.-Atmos., 108, 8425, doi:10.1029/2001JD001213, 2003.

Jimenez, J. L., Canagaratna, M. R., Donahue, N. M., Prevot, A. S. H., Zhang, Q., Kroll, J. H., DeCarlo, P. F., Allan, J. D., Coe, H., Ng, N. L., Aiken, A. C., Docherty, K. S., Ulbrich, I. M., Grieshop, A. P., Robinson, A. L., Duplissy, J., Smith, J. D., Wilson, K. R., Lanz, V. A., Hueglin, C., Sun, Y. L., Tian, J., Laaksonen, A., Raatikainen, T., Rautiainen, J., Vaattovaara, P., Ehn, M., Kulmala, M., Tomlinson, J. M., Collins, D. R., Cubison, M. J., Dunlea, E. J., Huffman, J. A., Onasch, T. B., Alfarra, M. R., Williams, P. I., Bower, K., Kondo, Y., Schneider, J., Drewnick, F., Borrmann, S., Weimer, S., Demerjian, K., Salcedo, D., Cottrell, L., Griffin, R., Takami,A., Miyoshi, T., Hatakeyama, S., Shimono, A., Sun, J. Y., Zhang, Y. M., Dzepina, K., Kimmel, J. R., Sueper, D., Jayne, J. T., Herndon, S. C., Trimborn, A. M., Williams, L. R., Wood, E. C., Middlebrook, A. M., Kolb, C. E., Baltensperger, U., and Worsnop, D. R.: Evolution of Organic Aerosols in the Atmosphere, Science, 326, 1525, doi:10.1126/science.1180353, 2009.

Kerminen, V. M., Pirjola, L., Boy, M., Eskola, A., Teinnilä, K., Laakso, L., Asmi, A., Hienola, J., Lauri, A., Vainio, V., Lehtinen, K., and Kulmala, M.: Interaction between $\mathrm{SO}_{2}$ and submicron atmospheric particles, Atmos. Res., 54, 41-57, 2000.

Kim, E. and Hopke, P. K.: Comparison between conditional probability function and nonparametric regression for fine particle source directions, Atmos. Environ., 38, 4667-4673, 2004.

Kittelson, D. B.: Engines and Nano-particles: A Review, J. Aerosol Sci., 29, 575-588, 1998.

Kroll, J. H. and Seinfeld, J. H.: Chemistry of secondary organic aerosol: Formation and evolution of low-volatility organics in the atmosphere, Atmos. Environ., 42, 3593-3624, 2008.

Li, C. S., Lin, W. H., and Jenq, F. T.: Size distributions of submicrometer aerosols from cooking, Environ. Int., 19, 147-154, 1993. 
Liu, Q., Sun, Y., Hu B., Liu, Z. R., Akio S., and Wang, Y. S.: In situ measurement of $\mathrm{PM}_{1}$ organic aerosol in Beijing winter using a high-resolution aerosol mass spectrometer, Chin. Sci. Bull., 57, 819-826, 2012.

Norris, G., Vedantham, R., Wade, K., Brown, S., Prouty, J., and Foley C.: EPA Positive Matrix 5 Factorization (PMF)3.0, Fundamentals User Guide US Environmental Protection Agency, Office of Research and Development Washington DC, 20460, USA, 2008.

Ogulei, D., Hopke, P. K., Zhou, L. M., Pancras, J. P., Nair, N., and Ondov, J. M.: Source apportionment of Baltimore aerosol from combined size distribution and chemical composition data, Atmos. Environ., 40, 396-410, 2006.

10 Ondov, J. M. and Wexler, A. S.: Where do particulate toxins reside? An improved paradigm for the structure and dynamics of the urban mid-Atlantic aerosol, Environ. Sci. Technol., 32, 2547-2555, 1998.

Paatero, P.: Least squares formulation of robust nonnegative factor analysis, Chemom. Intell. Lab. Syst., 37, 23-35, 1997.

Paatero, P. and Tapper, U.: Positive matrix factorization: a non-negative factor model with optimal utilization of error estimates of data values, Environmetrics, 5, 111-126, 1994.

Park, S. S., Ondov, J. M., Harrison, D., and Nair, N. P.: Seasonal and shorter-term variations in particulate atmospheric nitrate in Baltimore, Atmos. Environ., 39, 2011-2020, 2005.

Peters, A., Skorkovsky, J., Kotesovec, F., Brynda, J., Spix, C., Wichmann, H. E., and Heinrich, J.: Associations between mortality and air pollution in Central Europe, Environ. Health Perspect., 108, 283-287, 2000.

Pey, J., Querol, X., Alastuey, A., Rodríguez, S., Putaud, J. P., and Dingenen, R. V.: Source apportionment of urban fine and ultra-fine particle number concentration in a Western Mediterranean city, Atmos. Environ., 43, 4407-4415, 2009.

Polissar, A. V., Hopke, P. K., and Poirot, R. L.: Atmospheric aerosol over Vermont: chemical composition and sources. Environ. Sci. Technol., 35, 4604-4621, 2001.

Rollins, A. W., Browne, E. C., Min, K. E., Pusede, S. E., Wooldridge, P. J., Gentner, D. R., Goldstein, A. H., Liu, S., Day, D. A., Russell, L. M., and Cohen R. C.: Evidence for $\mathrm{NO}_{\mathrm{x}}$ control over nighttime SOA formation, Science, 337, 1210-1212, 2012.

30 Seinfeld, J. H. and Pandis, S. N.: Atmospheric Chemistry and Physics: From air Pollution to climate change, Wiley, New York, USA, 267 pp., 2006.

\section{ACPD}

$13,1367-1397,2013$

\section{Source \\ apportionment of \\ ambient fine particle}

Z. R. Liu et al.

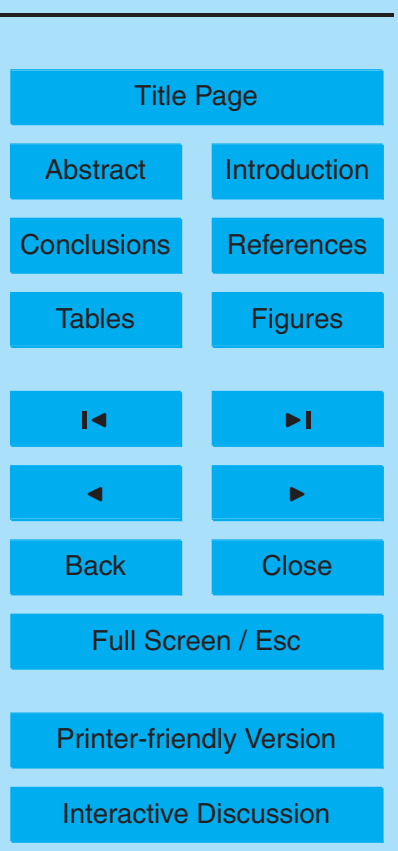


Song, Y., Zhang, Y. H., Xie, S. D., Zeng, L. M., Zheng, M., Salmon, L. G.,Shao, M., and Slanina, S.: Source apportionment of $\mathrm{PM}_{2.5}$ in Beijing by positive matrix factorization, Atmos. Environ., 40, 1526-1537, 2006.

Song, Y., Tang, X. Y., Xie, S. D, Zhang, Y. H.,Wei, Y. J., Zhang, M. S., Zeng, L. M., and Lu, S. $\mathrm{H}$.: Source apportionment of $\mathrm{PM}_{2.5}$ in Beijing in 2004, J. Haz. Mater., 146, 124-130, 2007.

Sun, Y. L., Zhang, Q., Schwab, J. J., Chen, W. N., Bae, M. S., Lin, Y. C., Hung, H. M., and Demerjian, K. L.: A case study of aerosol processing and evolution in summer in New York City, Atmos. Chem. Phys., 11, 12737-12750, doi:10.5194/acp-11-12737-2011, 2011 a.

Sun, Y.-L., Zhang, Q., Schwab, J. J., Demerjian, K. L., Chen, W.-N., Bae, M.-S., Hung, H.-M., Hogrefe, O., Frank, B., Rattigan, O. V., and Lin, Y.-C.: Characterization of the sources and processes of organic and inorganic aerosols in New York city with a high-resolution time-offlight aerosol mass apectrometer, Atmos. Chem. Phys., 11, 1581-1602, doi:10.5194/acp-111581-2011, 2011b.

Wichmann, H. E., Spix, C., Tuch, T., Wöelke, G., Peters, A., Heinrich, J., Kreyling, W. G., and Heyder, J.: Daily mortality and fine and ultrafine particles in Erfurt, Germany, Part A: Role of particle number and particle mass, Health Effects Institute Research Report, 98, 5-86, 2000.

Willeke, K. and Baron, P. A.: Aerosol Measurement Principles, Techniques, and Applications, Van Nostrand Reinhold, Hoboken, NJ, 1993.

Wu, Z. J., Hu, M., Liu, S., Wehner, B., Bauer, S., Bling, A. M., Wiedensohler, A., Petäjä, T., Maso, M. D., and Kulmala M.: New particle formation in Beijing, China: Statistical analysis of a 1-year data set, J. Geophys. Res., 112, D09209, doi:10.1029/2006JD007406, 2007.

Xie, S. D., Liu, Z., Chen, T., and Hua, L.: Spatiotemporal variations of ambient $\mathrm{PM}_{10}$ source contributions in Beijing in 2004 using positive matrix factorization, Atmos. Chem. Phys., 8, 2701-2716, doi:10.5194/acp-8-2701-2008, 2008.

Yue, W., Stölzel, M., Cyrys J., Pitz, M., Heinrich, J., Kreyling, W. G., Wichmann, H. E., Peters, A., Wang, S., and Hopke, P. K.: Source apportionment of ambient fine particle size distribution using positive matrix factorization in Erfurt, Germany, Sci. Total Environ, 39, 133-144, 2008.

Zhang, K., Wang, Y. S., Wen, T. X., MesImani, Y., and Murray, F.: Properties of nitrate, sulfate 30 and ammonium in typical polluted atmospheric aerosols $\left(\mathrm{PM}_{10}\right)$ in Beijing, Atmos. Res., 84, 67-77, 2007.

ACPD

$13,1367-1397,2013$

\section{Source \\ apportionment of \\ ambient fine particle}

Z. R. Liu et al.

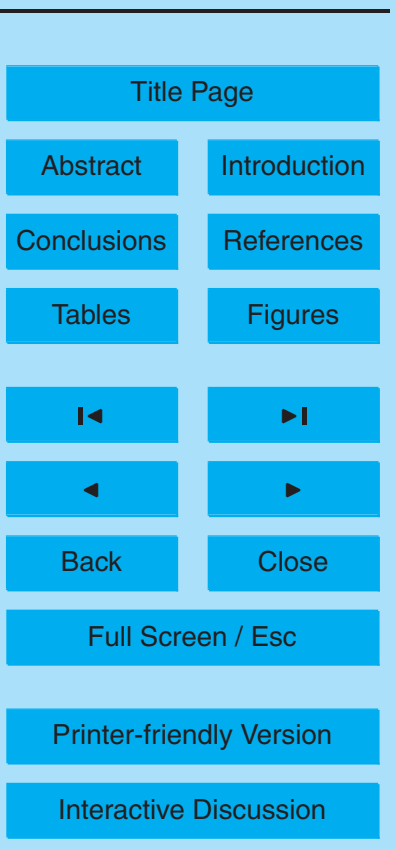


Zhang, Q. F., Gangupomu, R. H., Ramirez, D., and Zhu, Y. F.: Measurement of ultrafine particles and other air pollutants emitted by cooking activities, Int. J. Environ. Res., Public Health, 7, 1744-1759, doi:10.3390/ijerph7041744, 2010.

Zhang, Q., Canagaratna, M. R., Jayne, J. T., Worsnop, D. R., and Jimenez, J. L.: Time and size5 resolved chemical composition of submicron particles in Pittsburgh - Implications for aerosol sources and processes, J. Geophys. Res., 110, D07S09, doi:10.1029/2004JD004649, 2005.

Zhang, Q., Streets, D. G., Carmichael, G. R., He, K. B., Huo, H., Kannari, A., Klimont, Z., Park, I. S., Reddy, S., Fu, J. S., Chen, D., Duan, L., Lei, Y., Wang, L. T., and Yao, Z. L.: Asian emissions in 2006 for the NASA INTEX-B mission, Atmos. Chem. Phys., 9, 5131-5153, doi:10.5194/acp-9-5131-2009, 2009.

Zhao, Y. L., Hu, M., Slanina, S., and Zhang Y. H.: Chemical Compositions of Fine Particulate Organic Matter Emitted from Chinese Cooking, Environ. Sci. Technol., 41, 99-105, 2007.

Zhou, L. M., Kim, E., Hopke, P. K., Stanier, C. O., and Pandis, S.: Advanced factor analysis on Pittsburgh particle size-distribution data special issue of aerosol science and technology on findings from the Fine Particulate Matter Supersites Program, Aerosol Sci. Technol., 38, 118-132, 2004.

Zhou, L. M., Hopke, P. K., Stanier, C. O., Pandis, S. N., Ondov, J. M., and Pancras, J. P.: Investigation of the relationship between chemical composition and size distribution of airborne particles by partial least squares (PLS) and positive matrix factorization (PMF), J. Geophys.

$20 \quad$ Res., 110, D07S18, doi:10.1029/2004JD005050, 2005.

Zhu, C. S., Chen, C. C., Cao, J. J., Tsai, C. J., Chou, C. C. K., Liu, S. C., and Roam, G. D.: Characterization of carbon fractions for atmospheric fine particles and nanoparticles in a highway tunnel, Atmos. Environ., 44, 2668-2673, 2010.

Zhu, L., Huang, X., Shi, H., Cai, X. H., and Song, Y.: Transport pathways and potential sources of $\mathrm{PM}_{10}$ in Beijing, Atmos. Environ., 45, 594-604, 2011.

Zhu, Y. F., Hinds, W. C., Kim, S., and Sioutas, C.: Concentration and Size Distribution of Ultrafine Particles Near a Major Highway, J. Air Waste Manage. Assoc., 52, 1032-1042, 2002.

\section{ACPD}

$13,1367-1397,2013$

\section{Source \\ apportionment of \\ ambient fine particle}

Z. R. Liu et al.

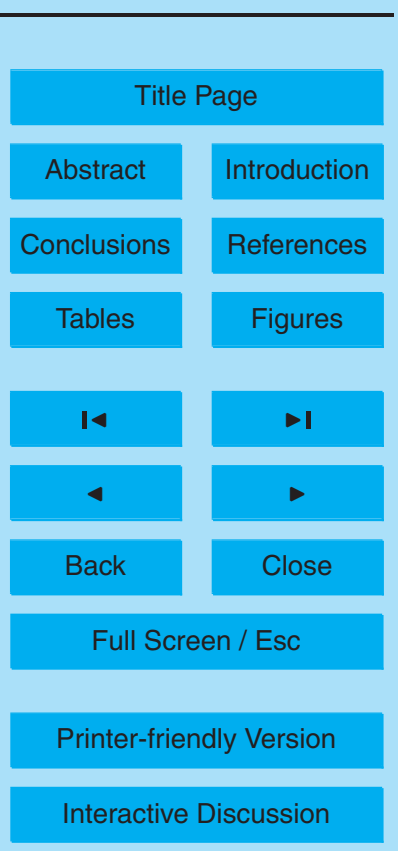




\section{ACPD}

13, 1367-1397, 2013

\section{Source \\ apportionment of \\ ambient fine particle}

Table 1. Attribution of mean particle number and volume to tentatively assigned sources.

\begin{tabular}{lll}
\hline \multirow{2}{*}{ Factors } & \multicolumn{2}{l}{ mean concentration (s.d.) (\%) } \\
\cline { 2 - 3 } & number & volume \\
\hline Local sources & & \\
cooking (factor 1) & $22.8(16.6)$ & $3.8(5.9)$ \\
exhaust, solid mode (factor 2) & $18.8(13.8)$ & $8.7(8.1)$ \\
exhaust, nucleation mode (factor 3) & $18.7(14.1)$ & $2.4(3.9)$ \\
secondary nitrate (factor 5) & $8.9(7.5)$ & $5.6(4.9)$ \\
secondary sulfate (factor 6) & $7.9(9.1)$ & $10.5(11.6)$ \\
coal-fired power plant (factor 7) & $6.8(8.3)$ & $21.3(19.1)$ \\
road dust (factor 8) & $2.3(1.8)$ & $15.5(9.5)$ \\
subtotal & 86.2 & 67.8 \\
Regional sources & & \\
accumulation mode (factor 4) & $13.8(10.5)$ & $32.2(17.5)$ \\
subtotal & 13.8 & 32.2 \\
\hline
\end{tabular}

Z. R. Liu et al.

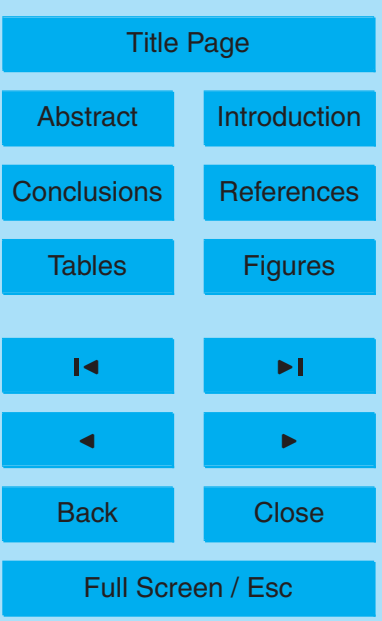

Printer-friendly Version

Interactive Discussion

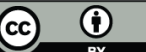




\section{ACPD}

13, 1367-1397, 2013

Table 2. Percent of each chemical species attributed to each factor.

\begin{tabular}{|c|c|c|c|c|c|c|c|c|}
\hline Species* & Factor 1 & Factor 2 & Factor 3 & Factor 4 & Factor 5 & Factor 6 & Factor 7 & Factor 8 \\
\hline org_AtM & 15.1 & 4.6 & 7.8 & 9.8 & 30.6 & 24.2 & 5.6 & 2.2 \\
\hline org_CoM & 34.7 & 21.7 & 0.0 & 6.1 & 17.0 & 13.5 & 3.3 & 3.7 \\
\hline org_DrM & 11.9 & 17.8 & 0.0 & 21.2 & 22.0 & 15.6 & 0.0 & 11.5 \\
\hline $\mathrm{NO}_{3}$ AtM & 5.2 & 6.1 & 5.9 & 0.0 & 47.8 & 30.9 & 4.1 & 0.0 \\
\hline $\mathrm{NO}_{3} \mathrm{CoM}$ & 6.0 & 22.7 & 2.7 & 8.1 & 39.7 & 15.7 & 1.5 & 3.6 \\
\hline $\mathrm{NO}_{3}$-DrM & 0.0 & 3.5 & 0.0 & 42.1 & 44.7 & 0.0 & 0.0 & 9.7 \\
\hline $\mathrm{SO}_{4}$ AtM & 2.2 & 4.9 & 3.8 & 15.6 & 33.2 & 28.8 & 11.1 & 0.4 \\
\hline $\mathrm{SO}_{4} \mathrm{CoM}$ & 2.1 & 15.3 & 3.5 & 17.9 & 27.6 & 25.4 & 8.3 & 0.0 \\
\hline $\mathrm{SO}_{4-D r M}$ & 0.0 & 0.0 & 0.0 & 37.3 & 24.0 & 28.2 & 10.5 & 0.0 \\
\hline $\mathrm{NH}_{4}$ AtM & 4.5 & 12.0 & 13.7 & 0.0 & 35.4 & 30.3 & 0.0 & 4.0 \\
\hline $\mathrm{NH}_{4} \mathrm{CoM}$ & 4.7 & 17.1 & 10.2 & 0.0 & 33.7 & 26.3 & 2.9 & 5.0 \\
\hline $\mathrm{NH}_{4}$-DrM & 2.3 & 4.3 & 3.7 & 23.8 & 36.3 & 24.3 & 3.1 & 2.2 \\
\hline Cl_AtM & 0.0 & 4.6 & 8.2 & 6.3 & 47.8 & 23.0 & 5.1 & 4.9 \\
\hline Cl_CoM & 0.5 & 4.8 & 8.1 & 7.6 & 48.4 & 21.8 & 4.7 & 4.0 \\
\hline Cl_DrM & 0.0 & 3.9 & 7.0 & 10.6 & 50.5 & 17.7 & 5.0 & 5.4 \\
\hline NO & 0.0 & 0.0 & 16.7 & 13.9 & 56.3 & 0.0 & 13.0 & 0.0 \\
\hline $\mathrm{NO}_{2}$ & 7.3 & 6.5 & 9.9 & 11.3 & 35.8 & 15.2 & 0.5 & 13.4 \\
\hline $\mathrm{O}_{3}$ & 7.1 & 0.0 & 0.7 & 10.1 & 0.0 & 82.1 & 0.0 & 0.0 \\
\hline $\mathrm{SO}_{2}$ & 0.0 & 1.4 & 0.0 & 5.3 & 50.1 & 31.9 & 11.4 & 0.0 \\
\hline $\mathrm{CO}^{\circ}$ & 4.4 & 1.6 & 2.7 & 18.2 & 44.2 & 15.5 & 12.3 & 1.0 \\
\hline
\end{tabular}

Source

apportionment of ambient fine particle

Z. R. Liu et al.
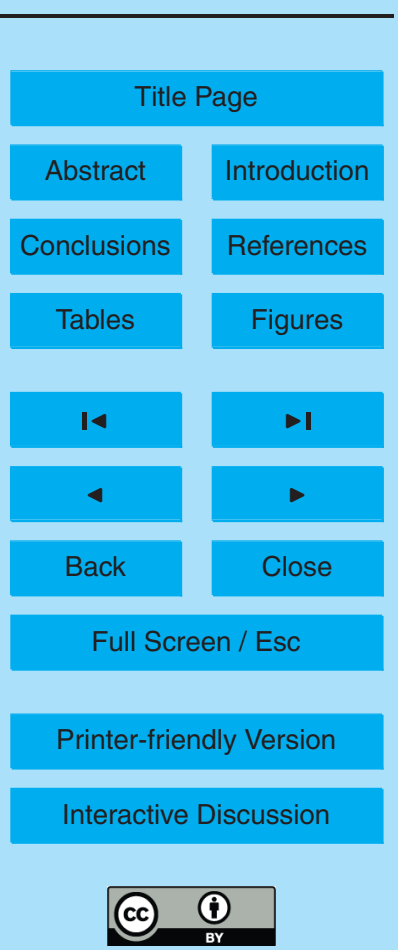


\section{ACPD}

13, 1367-1397, 2013

\section{Source \\ apportionment of ambient fine particle}

Table 3. Comparison of source contribution (\%) to ambient $\mathrm{PM}_{2.5}$ in Beijing and other mega cities by different studies.

\begin{tabular}{|c|c|c|c|c|c|c|c|c|}
\hline \multirow[t]{2}{*}{ Sources } & \multirow{2}{*}{$\begin{array}{l}\text { Song et al. (2006) } \\
2000 \text {, annual } \\
\text { Beijing } \\
\text { mass }^{\text {a }}\end{array}$} & \multirow{2}{*}{$\begin{array}{l}\text { Song et al. (2007) } \\
2004, \text { August } \\
\text { Beijing } \\
\text { mass }^{\text {a }}\end{array}$} & \multirow{2}{*}{$\begin{array}{l}\text { Chen et al. (2012) } \\
2001-2005 \\
\text { North Birmingham } \\
\text { mass }^{\text {a }}\end{array}$} & \multirow{2}{*}{$\begin{array}{l}\text { Pey et al. (2009) } \\
2003-2004 \\
\text { Barcelona } \\
\text { number }^{c}\end{array}$} & \multicolumn{2}{|c|}{$\begin{array}{l}\text { Harrison, et al. (2011) } \\
\text { 2007, October-November } \\
\text { London }\end{array}$} & \multicolumn{2}{|c|}{$\begin{array}{l}\text { This Study } \\
\text { 2011, August } \\
\text { Beijing }\end{array}$} \\
\hline & & & & & volume $^{b}$ & number $^{c}$ & volume $^{\mathrm{b}}$ & number $^{c}$ \\
\hline Motor vehicle & 5.9 & 14.9 & 15.6 & 64.2 & 22.4 & 65.4 & 11.1 & 37.5 \\
\hline Secondary sulfate & 17.0 & 24.1 & 24.0 & 3.3 & & & 10.5 & 7.9 \\
\hline Secondary nitrate & 16.0 & 8.0 & 5.3 & & 8.4 & 2.0 & 5.6 & 8.9 \\
\hline Coal consumption & 16.8 & 11.3 & & & & & 21.3 & 6.8 \\
\hline Road dust & 7.5 & 8.4 & 3.1 & 1.4 & 18.1 & 6.5 & 15.5 & 2.3 \\
\hline Regional & & & & 24.2 & 29.3 & 5.7 & 32.2 & 13.8 \\
\hline Cooking & & & 2.0 & & 6.7 & 6.6 & 3.8 & 22.8 \\
\hline Others & 36.9 & 33.1 & 50.0 & 6.9 & 15.1 & 13.8 & & \\
\hline
\end{tabular}

${ }^{\text {a }}$ Mass concentration contribution (\%) of each factor to $\mathrm{PM}_{2.5}$.

${ }^{b}$ Volume concentration contribution (\%) of each factor to $\mathrm{PM}_{2.5}$.

${ }^{\mathrm{C}}$ Number concentration contribution (\%) of each factor to $\mathrm{PM}_{2.5}$.

Z. R. Liu et al.

Title Page

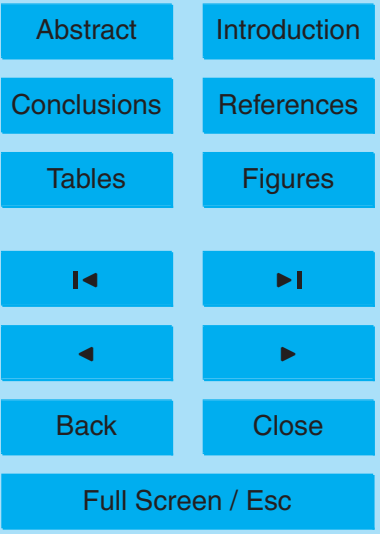

Printer-friendly Version

Interactive Discussion 

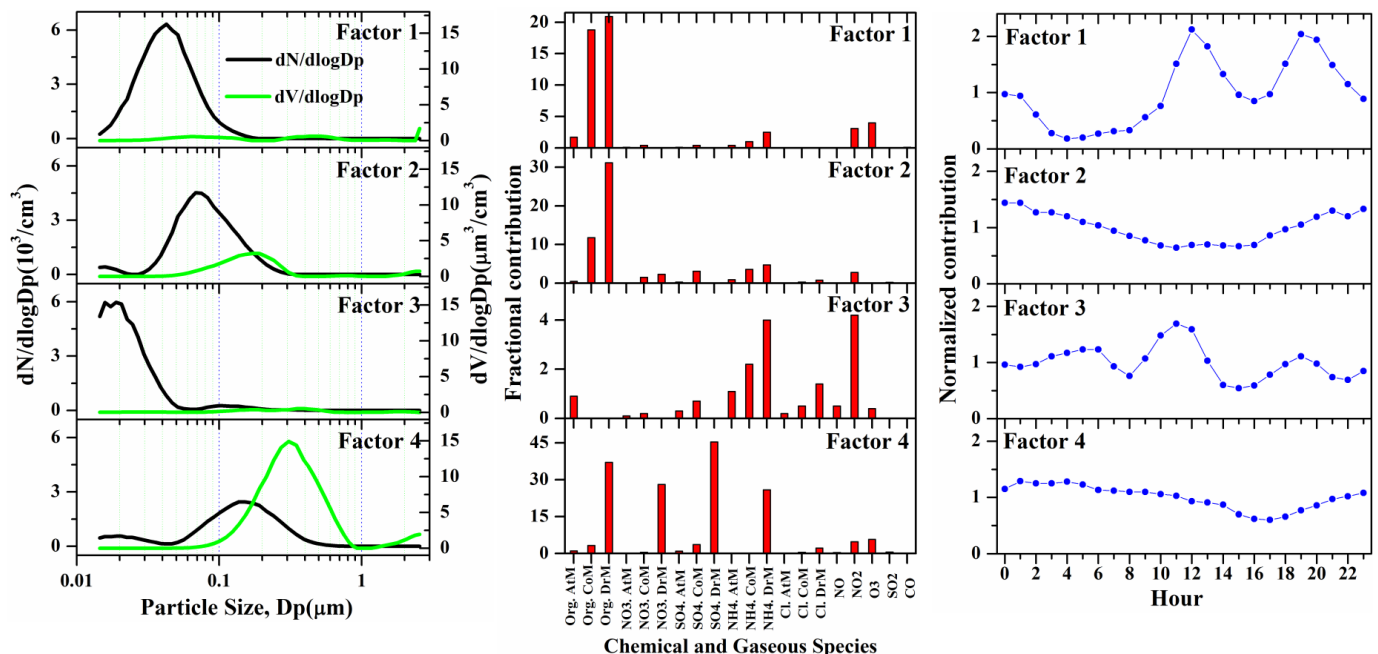

Fig. 1. Profiles of the resolved sources including particle composition, gaseous species, and size distribution information for the first four sources. Chemical species were divided in Aitken mode (AtM), condensation mode (CoM) and droplet mode (DrM).

\section{ACPD}

13, 1367-1397, 2013

\section{Source \\ apportionment of ambient fine particle}

Z. R. Liu et al.

\section{Title Page}

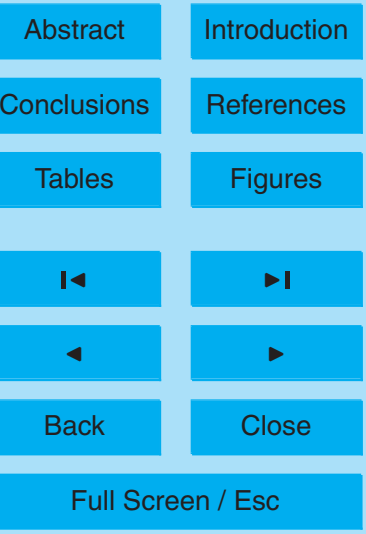

Printer-friendly Version

Interactive Discussion 


\section{ACPD}

13, 1367-1397, 2013
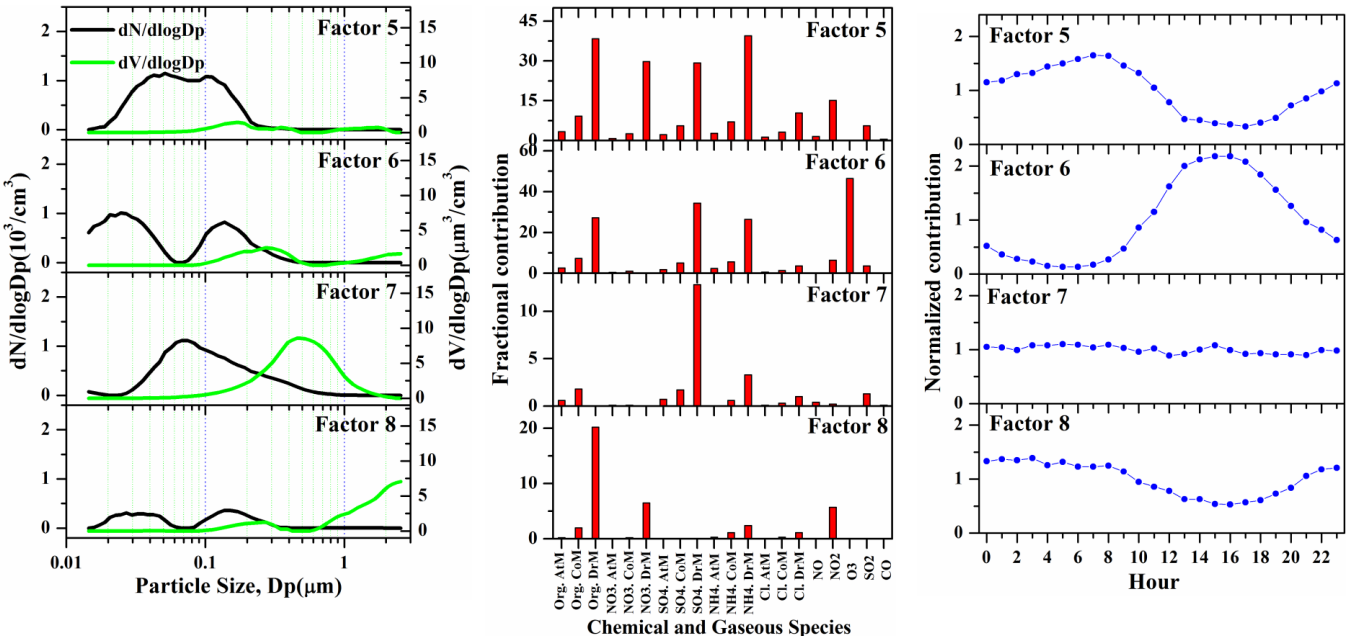

Fig. 2. Profiles of the resolved sources including particle composition, gaseous species, and size distribution information for sources 5-8 Chemical species were divided in Aitken mode (AtM), condensation mode (CoM) and droplet mode (DrM).

\section{Source \\ apportionment of ambient fine particle}

Z. R. Liu et al.

Title Page

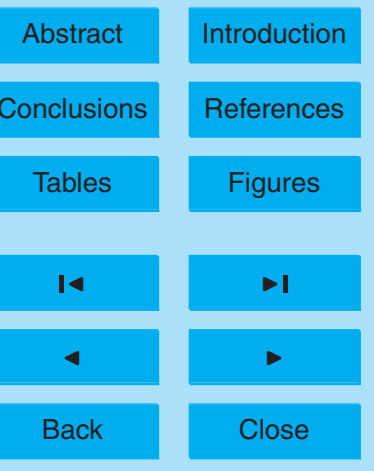

Full Screen / Esc

Printer-friendly Version

Interactive Discussion 

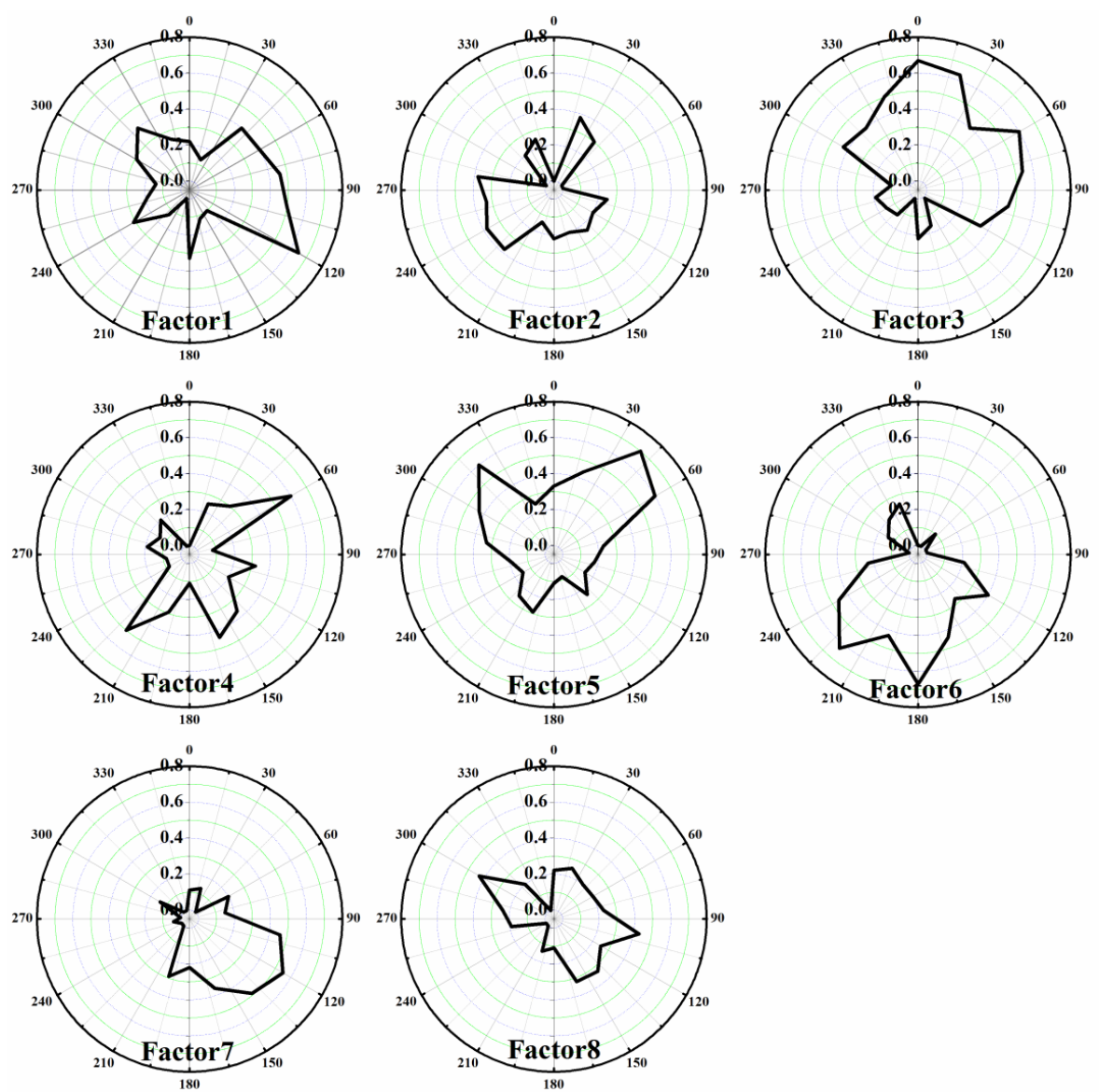

Fig. 3. Conditional probability function (CPF) plots for the resolved source contributions using a 75th percentile criterion.

\section{ACPD}

13, 1367-1397, 2013

\section{Source \\ apportionment of ambient fine particle}

Z. R. Liu et al.

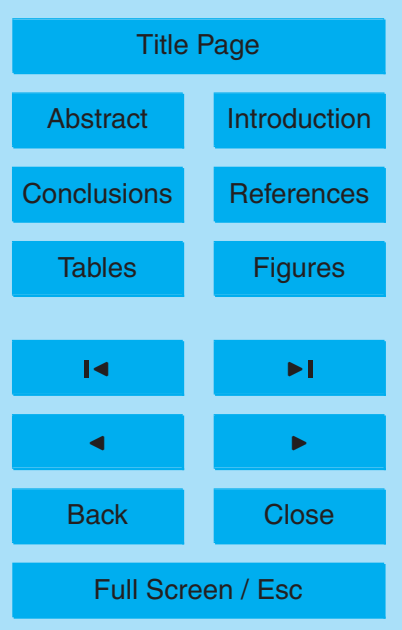

Printer-friendly Version

Interactive Discussion

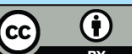




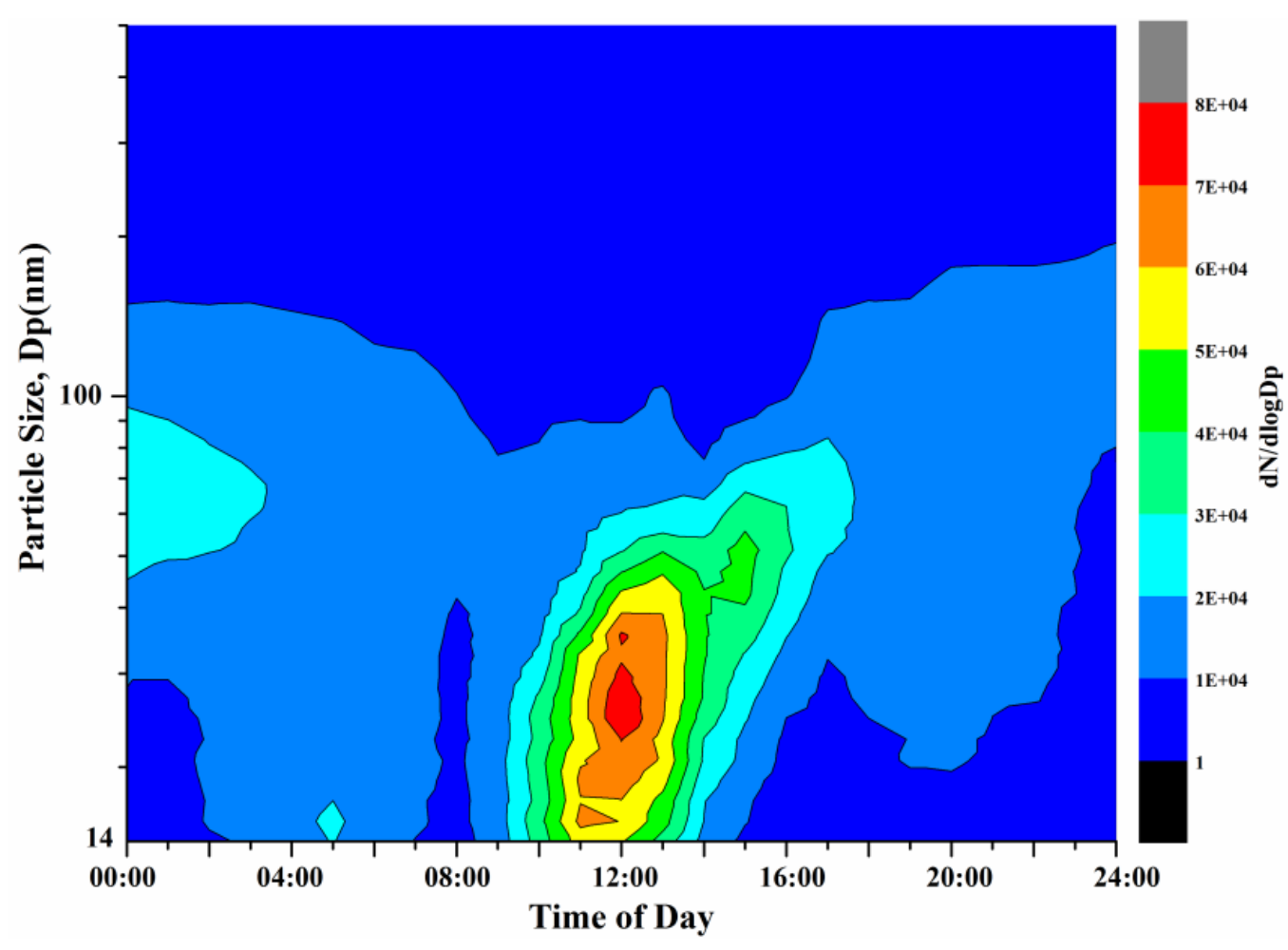

Fig. 4. Plot of the particle size distributions as a function of time-of-day for 31 July 2011 showing a nucleation and growth event.

\section{ACPD}

13, 1367-1397, 2013

\section{Source \\ apportionment of ambient fine particle}

Z. R. Liu et al.

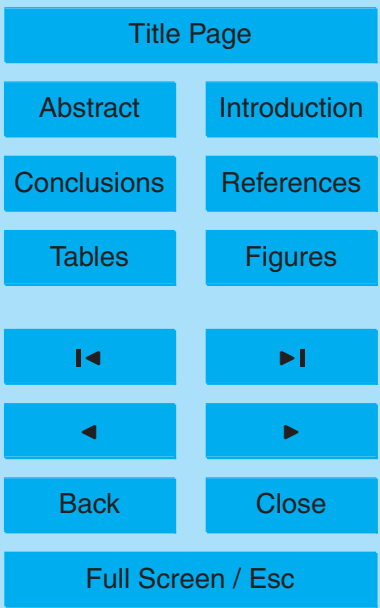

Printer-friendly Version

Interactive Discussion 